\title{
LA PEDAGOGÍA SOCIAL EN ESPAÑA: DE LA RECONSTRUCCIÓN ACADÉMICA Y PROFESIONAL A LA INCERTEZA CIENTÍFICA Y SOCIAL
}

\author{
SOCIAL PEDAGOGY IN SPAIN: \\ FROM ACADEMIC AND PROFESSIONAL RECONSTRUCTION \\ TO SCIENTIFIC AND SOCIAL UNCERTAINTY
}

\section{A PEDAGOGIA SOCIAL NA ESPANHA: DA RECONSTRUÇÃO ACADEMICA E PROFISSIONAL À INCERTEZA CIENTÍFICA E SOCIAL}

\author{
Martí Xavier March Cerdà, Carmen Orte Socias y Lluís Ballester Brage \\ UNIVERSITAT DE LES ILLES BALEARS
}

RESUMEN: Introducción y objetivos: se reflexiona sobre la realidad de la Pedagogía Social en España durante la segunda década del siglo XXI desde una perspectiva analítica con la finalidad de conocer y reconocer sus puntos débiles, sus puntos fuertes, sus amenazas y sus oportunidades. El análisis se centra en la revisión de la Pedagogía Social como disciplina clave en la reconstrucción de las Ciencias de la Educación y como respuesta socioeducativa a las demandas y necesidades de la sociedad y del Estado de Bienestar. El análisis de la situación actual se completa a partir de una investigación centrada en los estudios de Educación Social. El universo de referencia está configurado por el conjunto de los centros universitarios en los que se ofrecen estudios de educación social en España. Las variables sobre las que se estructuró la recogida de información fueron: 1) la estructura de la oferta, 2) las características de la formación ofrecida, 3) los resultados formativos Metodología: La muestra realizada es de tipo estructural, seleccionando 11 universidades que desarrollan los estudios en tres zonas del Estado: el norte del país, el centro y el sur, así como la zona mediterránea. La recogida de la información se ha realizado con dos metodologías complementarias: un cuestionario, acordado en el contexto de la Sociedad Iberoamericana de Pedagogía Social (SIPS), de respuesta sobre web; una revisión de las web de las propias universidades que ofrecen estudios de educación social. Análisis y tratamiento de los datos: el análisis se realizó en dos fases complementarias. Primero, las preguntas cerradas se trataron con SPSS. Los registros digitales de las preguntas abiertas fueron tratados con el programa NVIVO. Resultados: La gran mayoría de la oferta de enseñanza es presencial, aunque hay algunas experiencias de formación a distancia. En cuanto a las dimensiones de la oferta, la media se sitúa en torno a las 87 plazas. Respecto a la oferta 
de doble titulación Educación Social/Trabajo Social, indicar que ésta es aún testimonial. En la impartición del Grado hay implicación multidepartamental, aunque con mayor protagonismo de los departamentos de Pedagogía, y la implicación de todos los ámbitos socioeducativos. Respecto a las competencias más importantes, destacar el diagnóstico, el diseño de proyectos y la gestión de los mismos, entre las más importantes. El profesorado que imparte la titulación tiene un nivel formativo elevado y, en lo que respecta a las metodologías docentes o a la evaluación, ambas han ido variando des de el inicio de la titulación, y ampliándose la variedad de las mismas. Discusión: a partir de la reflexión teórica y el análisis de datos, se discute sobre la oportunidad de la Pedagogía Social para superar el impasse en el que está en este momento, aún a pesar del desarrollo y auge de los estudios de educación social en los últimos veinte años. Se discute la necesidad de incorporar la investigación basada en evidencias como fundamento de la acción socioeducativa, y como necesidad para seguir avanzando en el desarrollo de la Pedagogía Social y en la acreditación del profesional de la educación social.

PALABRAS CLAVE: pedagogía social; educación social; intervención socioeducativa basada en evidencias.

ABSTRACT: Introduction and aims: A reflection on the reality of Social Pedagogy in Spain during the second decade of the 21st century from an analytical perspective, with the aim of finding out and recognising its weak points, its strong points, its challenges and its opportunities. The analysis centres on reviewing Social Pedagogy as a key discipline in the reconstruction of Educational Sciences and a socio-educational response to the demands and needs of society and the Welfare State. Analysis of the current situation is completed with research into Social Education studies. The sphere of reference is made up of the group of universities offering social education courses in Spain. The variables structuring the data capture were: 1) the structure of the offer, 2) the features of the courses offered, and 3) course results. Methodology: The sample taken was structural in nature, selecting 11 universities holding the courses in three areas of Spain - the North, Central and Southern Spain and the Mediterranean region. Information was gathered using two complementary methodologies, a questionnaire, falling within the context of the Ibero-American Social Education Society (SIPS), and a review of the web sites of the universities offering courses in social education. Data processing and analysis: The analysis was carried out in two complementary stages. First of all, the closed questions were processed using SPSS and then the digital records of the open questions were processed using the NVIVO program. Results: The large majority of the courses on offer are classroom-based, with some distance learning courses being available. The average size of the courses was around 87 places. It should be pointed out that the double degree in Social Education and Social Work on offer is merely symbolic. There is multi-departmental involvement in teaching the Degree, although a larger role is played by the Pedagogy departments and all socio-educational fields are involved. Within the most important skills, diagnostics and project design and management stand out. The professors teaching the courses are highly qualified and, with respect to teaching methodologies and assessments, these have changed and broadened out since the course was first held. Discussion: Theoretical reflection and data analysis is used to discuss the chance for Social Education to overcome the impasse in which it currently finds itself, in spite of the development and growth in social education studies over the last twenty years. The need is discussed to include evidence-based research as a basis for socio-educational action and as a necessity to continue to move forward in Social Education and the qualification of socio-educational professionals.

[ 46 ] MARTÍ XAVIER MARCH CERDÀ, CARMEN ORTE SOCIAS Y LLUÍS BALLESTER BRAGE SIPS - PEDAGOGIA SOCIAL. REVISTA INTERUNIVERSITARIA [1139-1723 (2016) 27, 45-82] TERCERA ÉPOCA 
KEYWORDS: social pedagogy; social education; evidence-based socio-educational intervention.

RESUMO: Introdução e objetivos: busca a reflexão sobre a realidade da Pedagogia Social na Espanha durante a segunda década do século XXI desde uma perspectiva analítica com a finalidade de conhecer e reconhecer seus pontos frágeis, seus pontos fortes, suas ameaças e suas oportunidades. A análise se centra na revisão da Pedagogia Social como disciplina chave na reconstrução da das Ciências da Educação e como resposta socioeducativa as demandas e necessidades da sociedade do Estado de Bem Estar Social. A análise da situação atual se completa a partir de uma investigação focalizada nos estudos da Educação Social. O universo de referência está configurado pelo conjunto dos centros universitários nos quais se oferecem estudos de educação social na Espanha. As variáveis sobre as quais se construiu a coleta de dados foram: 1) a estrutura da oferta; 2) as características da formação oferecida ; 3) os resultados formativos. Metodologia: a mostra realizada é do tipo estrutural, selecionando 11 universidades que desenvolvem os estudos em três zonas do Estado: o norte do país, o entro e o sul, assim como a zona mediterrânea. A coleta das informações foi realizada com duas metodologias complementares: um questionário, aprovado no contexto da Sociedade Iberoamericana de Pedagogia Social (SIPS), respondido via web, uma revisão da web das próprias universidades que oferecem estudos de educação social. Análise e tratamento dos dados: a análise foi realizada em duas fases complementares. Primeiro, as perguntas fechadas foram submetidas ao SPSS. Os registros digitais das perguntas abertas foram submetidas ao programa NVIVO. Resultados: A grande maioria da oferta de ensino é presencial, ainda que haja algumas experiências de formação a distância. A respeito das dimensões da oferta, a média se situa em torno as 87 vagas. A respeito da oferta de dupla titulação Educação Social/Trabalho Social, esta é ainda um processo sendo testado. Na organização da Graduação existe implicações multidepartamentais, ainda que com maior protagonismo dos departamentos de Pedagogia, e a implicação de todos os âmbitos socioeducativos. A respeito das competências mais importantes, destaca-se o diagnóstico, o desenho de projetos e a gestão dos mesmos, entre os mais importantes. Os professores que atuam nos cursos possuem um nível de formação elevado e, a respeito das metodologias docentes ou de avaliação, ambas têm variado desde o início da titulação como também ampliado a variedade das mesmas. Discussão: a partir da reflexão teórica e da análise dos dados, se discute sobre a oportunidade da Pedagogia Social para superar o impasse que se vive nesse momento, mesmo com o desenvolvimento e auge dos estudos de educação social nos últimos vinte anos. Se discute a necessidade de incorporar a investigação embasada em evidências como fundamento da ação socioeducativa, e como necessidade para seguir avançando no desenvolvimento da Pedagogia Social e na certificação do profissional da educação social.

PALAVRAS-CHAVE: pedagogia social; educação social; intervenção socioeducativa fundamentada em evidências. 


\section{Introducción: la realidad contradictoria de la Pedagogía Social}

¿Cual es la realidad de la Pedagogía Social en España durante la segunda década del siglo XXI? Se trata de una pregunta a la que no resulta fácil contestar en un artículo que por sus dimensiones no puede abordar en profundidad todos los aspectos de la misma; desde la perspectiva epistemológica hasta la perspectiva investigadora, pasando por la profesional, la académica, la histórica, la social o la política. Sin embargo, después de décadas de un proceso de reconstrucción y de recuperación, en todos los sentidos, de esta disciplina socioeducativa, es necesario realizar una aproximación analítica al estado de la cuestión de la misma, con el fin de conocer y reconocer sus puntos débiles, sus puntos fuertes, sus amenazas y sus oportunidades.

Se trata, pues, de un análisis que pretende poner blanco sobre negro la realidad y perspectivas de la Pedagogía Social, en tanto que disciplina clave no sólo de la reconstrucción de las Ciencias de la Educación, sino también de la respuesta socioeducativa a los problemas escolares y a las demandas y necesidades de la sociedad y del Estado de Bienestar. En este contexto, uno de los hechos más relevantes en el campo académico y profesional de las ciencias de la educación de la última década del pasado siglo, en nuestro país, fue -es todavía y será, sin duda alguna- el proceso de reconstrucción de la pedagogía social, en tanto que vieja y nueva disciplina educativa que configura la respuesta social de la educación a los problemas y a las necesidades sociales y educativas (Caride, Gradaílle, \& Caballo, 2015). Efectivamente, si realizamos un análisis evolutivo de la pedagogía social podemos señalar, como hecho más significativo, el renacimiento de una vieja disciplina, que había quedado obsoleta, en el marco de unas ciencias de la educación que miraban más el pasado que el presente y que eran incapaces de llevar a cabo un proceso de renovación y de actualización académica, profesional y social. La irrupción de nuevas disciplinas, con otra historia y otro

\section{Introduction: The Contradictory Reality of Social Pedagogy}

What is the current situation of social pedagogy in Spain in the second decade of the 21st century? This is not an easy question to answer in a paper of this size, where an in-depth study of different walks of social pedagogy from an epistemological, research-related, professional, academic, historical, social and political perspective is impossible. Nonetheless, after decades of a process of revival and reconstruction of this socio-educational discipline in all senses of the word, a study is needed of the current state of social pedagogy in order to determine its weak and strong points, together with the threats it faces and the opportunities that it offers.

By this, I mean a study directed at shedding light on the current situation and future prospects of social pedagogy as a key discipline, not just in the reconstruction of educational science but also in socio-educational responses to problems in schools and to the needs and demands of society and the welfare state. In this context, during the 1990s in Spain, one of the most significant events at academic and professional levels of educational science was the revival and reconstruction of social pedagogy in its capacity as an old and yet new educational discipline aimed at offering a socio-educational response to social and educational problems and needs (Caride, Gradaílle, \& Caballo, 2015). Indeed, if we look at the evolution of social pedagogy, what is most significant is the fact that we are talking about the rebirth of a discipline that had become obsolete in the background context of an educational science that looked more to the past than to the present and which was incapable of carrying out a process of academic, professional and social renewal. The emergence of new disciplines, with a different background history and approach, only served to confirm the obsolescence of this former discipline.

In this context, the gradual re-emergence of social pedagogy within the panorama of differing educational disciplines has not just sig-

[ 48 ] MARTÍ XAVIER MARCH CERDÀ, CARMEN ORTE SOCIAS Y LLUÍS BALLESTER BRAGE SIPS - PEDAGOGIA SOCIAL. REVISTA INTERUNIVERSITARIA [1139-1723 (2016) 27, 45-82] TERCERA ÉPOCA 
planteamiento, certificó la obsolescencia de la antigua pedagogía.

En este contexto, la irrupción progresiva de la pedagogía social dentro del panorama de las diversas disciplinas educativas no solo ha significado un proceso de cambio en el ámbito de la vieja pedagogía, sino también la sistematización académica y profesional de diversas disciplinas pedagógicas. Además, ha implicado una aproximación más clara de las ciencias de la educación a los nuevos retos, interrogantes y desafíos con los que se enfrenta la educación en un nuevo siglo lleno de incertidumbres de todo tipo. Esta reconstrucción de la pedagogía social se ha fundamentado, de facto, sobre dos elementos significativos: por una parte, sobre un desarrollo profesional e institucional desigual a través de la existencia de distintas figuras profesionales educadores de calle, de familia, de centros de tratamiento, de centros de protección; animadores juveniles, socioculturales; educadores de adultos, etc.- que sin una formación universitaria han ido dando respuestas a las necesidades sociales y educativas existentes. La creación, a principio de los años noventa, de la diplomatura en educación social supuso la institucionalización de una formación de carácter universitario y la convergencia de las diversas tradiciones de la educación social en una sola y única titulación. Un proceso que no solo ha sido ratificado con la creación del grado de Educación Social, sino también con la puesta en marcha de diversos másteres, enmarcados dentro del ámbito académico y profesional de la pedagogía social. Por otra parte, la pedagogía social se ha fundamentado sobre un desarrollo académico y científico que ha tenido en la Universidad un elemento fundamental desde la perspectiva de su definitiva institucionalización en el ámbito teórico, metodológico e investigador. Esto se ha traducido en la existencia de reflexiones sobre los diversos campos temáticos de la pedagogía social, en el desarrollo de líneas de investigación socioeducativas, en la presencia de un importante número de libros, revistas, jornadas, seminarios y congresos sobre esta temática de la educación social (Duţă, Forés \& Novella, 2015).

Esta institucionalización académica y universitaria de la pedagogía social ha tenido y está nified transformations to this pre-existing discipline but also the academic and professional systemization of different pedagogic disciplines. It has also led to educational science's closer contact with the new challenges and problems that education faces in a new century filled with uncertainties of all kinds. Social pedagogy's reconstruction has been mainly based on two processes: firstly, a somewhat unbalanced process of professional and institutional development through professional figures (street outreach workers, family service workers, workers at treatment and protection centres, youth workers, activity coordinators, adult educators etc.) without a formal university training who have been offering a response to existing social and educational needs. The institutionalization of training in this field and convergence of different socio-educational traditions in one single qualification came with the creation, in the early 1990s, of a university-level Diploma in Social Education. This process was further consolidated with the ensuing creation of a Degree in Social Education and the introduction of several master's degrees with academic and professional ties with the field of social pedagogy. At the same time, the revival of this discipline has also been founded on academic and scientific developments, with universities playing a key role in terms of its institutional integration in methodologies, theory and research. This has led to reflections on different thematic areas of social pedagogy, to the development of fields of socio-educational research, and to numerous publications, journals, conferences, seminars and congresses on this field of social education (Duţă, Forés \& Novella, 2015).

The integration of social pedagogy at academic and university levels has gone hand in hand, professionally and socially, with the creation and development of professional associations of community workers ("educadores sociales" in Spanish) in different Spanish regions and to the foundation of the General Council of Associations of Community Workers. This corporate and professional step forward has contributed to the employment of 
teniendo su correlato profesional y social con la creación, y desarrollo, de los colegios profesionales de educadores sociales en las diversas comunidades autónomas y del Consejo General de Colegios de Educadores Sociales. Un desarrollo corporativo y profesional que ha contribuido a la contratación de estos profesionales de la educación social en las diferentes administraciones públicas, en entidades, organizaciones sociales y empresas privadas, y en los diferentes ámbitos de intervención del educador social. Todo ello ha creado un conglomerado universitario, profesional y social que está consolidando la profesión de educador social y la disciplina de la pedagogía social (Pérez, 2003; Sáez \& Molina, 2006).

Por tanto, la institucionalización de la pedagogía social en España ha tenido estas líneas convergentes de trabajo; $y$ ello es importante que sea reseñado de una forma clara, por una serie de razones: en primer lugar, porque no es un hecho generalizado el trabajo colaborativo entre el mundo profesional y el mundo académico; en segundo lugar porque si algo ha caracterizado, durante la posguerra civil española y hasta ya entrado el proceso de restauración democrática, el mundo universitario de la pedagogía es su alejamiento de la realidad educativa cotidiana, con todo lo que ello ha implicado en el ámbito de la identidad profesional, del progreso académico y científico, de la conformación de una corporación universitaria, etc. Además, solo desde este trabajo colaborativo se debe entender la rápida institucionalización académica y profesional de la pedagogía y educación social (March \& Orte, 2014).

Sin embargo, la Pedagogía Social, en nuestra opinión, está llegando a una situación de un cierto impasse: por una parte es necesario saber cual es su realidad en las universidades españolas con el fin de calibrar las dificultades de crecimiento, pero por otra parte conocer las limitaciones que tiene para dar el salto cualitativo necesario desde la perspectiva científica. A todo ello hay que añadirle la problemática de la intervención socioeducativa desde la perspectiva de la evaluación de las acciones y la importancia para ello de las evidencias científicas. Es importante tener en cuenta el conocimiento these professionals by different public authorities, bodies, social organizations and private businesses and in different fields of social intervention. All this has led to the emergence of university, professional and social networks that are helping to consolidate social pedagogy as a discipline and community workers as a profession (Pérez, 2003; Sáez \& Molina, 2006).

It is important to highlight the converging repercussions of social pedagogy's institutional integration in Spain for a series of reasons: firstly, because collaborative initiatives between the business and academic worlds are not common and, secondly, because if the field of educational science was conspicuous for something, at university level, during the Spanish post-war period and early years of democracy, it was for its lack of contact with everyday educational realities, with all the ensuing implications in terms of professional identities, academic and scientific progress, and the creation of professional bodies. Furthermore, only through collaborative efforts of this kind can the swift institutional academic and professional integration of social pedagogy and social education be explained (March \& Orte, 2014).

Having said that, in our opinion, social pedagogy is reaching a certain impasse. In order to make qualitative scientific headway, it is important to gauge the reality of social pedagogy at Spanish universities so as to ascertain its possible development problems and identify its potential limitations. Another important issue is the evaluation of socio-educational interventions and the relevance of scientific evidence in this process. Gaining an insight into the reality of social education in universities, through different variables, is an important way of acquiring an overall vision of the different factors that form part of the global reality of social pedagogy. These are the aims of this paper. In any case, in this paper, we have used the concept of social pedagogy based on the aim of the concept, its perspective and its theoretical-methodological-research approach. Not only this concept is not in contradiction with the term of social education, but it is its

[50] MARTí XAVIER MARCH CERDÀ, CARMEN ORTE SOCIAS Y LLUÍS BALLESTER BRAGE SIPS - PEDAGOGIA SOCIAL. REVISTA INTERUNIVERSITARIA [1139-1723 (2016) 27, 45-82] TERCERA ÉPOCA 
sobre la realidad de la educación social en la universidad a través de diversas variables. Un aspecto necesario para poder tener una visión de conjunto de los diversos elementos que integran la realidad global de la Pedagogía Social. Estos son los objetivos del artículo. En todo caso, en este trabajo, hemos optado por el concepto de Pedagogía Social por el objetivo del mismo, por su planteamiento, por su enfoque teórico-metodológico-investigacional; un enfoque que no sólo no es contradictorio con el término de educación social, ya que él mismo es su razón de ser y de su existencia como disciplina que la estudia.

\section{La cultura de la evaluación como funda- mento de la Pedagogía Social}

La institucionalización definitiva de la Pedagogía Social y de la educación social necesita de un proceso correlativo de puesta en marcha de políticas claras y explícitas de evaluación de la misma. Y ello resulta totalmente necesario si se quiere pasar de un planteamiento no riguroso de esta disciplina a un enfoque serio, conociendo los procesos y los efectos de las diversas intervenciones socioeducativas. En este sentido es necesario poner de manifiesto la ausencia real de una cultura de la evaluación que de consistencia a la Pedagogía Social. Así, la ausencia en nuestro país de una cultura de la evaluación que analice, de una forma sistemática, rigurosa, responsable y útil, los diferentes sistemas de servicios, los procesos y resultados del Estado Social y de Derecho del cual nos hemos dotado, no es un hecho casual; la falta de esta cultura evaluativa refleja el resultado de una opción, de un planteamiento y de una política que ha abdicado de la evaluación en tanto que proceso de conocimiento de una realidad, de una intervención que se ha llevado a cabo, tanto desde la administración, como desde la misma sociedad civil.

Aunque evaluar conlleva múltiples implicaciones de diverso signo y dimensión, resulta evidente la necesidad de descartar los enfoques y las concepciones tecnocráticas, neutrales, asépticas y avalorativas que tiene la evaluación. Y ello, según Silverio Barriga (1990: 267-280): reason of being and of its existence as the discipline of study.

\section{Building a culture of evaluation as one of the cornerstones of social pedagogy}

For social pedagogy and social education to become fully integrated at an institutional level, the complementary introduction of clear, explicit policies regarding their evaluation is needed. This is crucial in order to move from a non-rigorous approach to this discipline to a serious one and to an understanding of the processes and effects of different socio-educational interventions. At this point, it is important to note the absence of a culture of evaluation that might lend greater weight to social pedagogy as a discipline. The absence of such practices in Spain for conducting systematic, rigorous, responsible, useful analyses of the different services, processes and outcomes of our Social Welfare State and democratic system is no mere coincidence. It is the result of a chosen option, of an attitude or policy of relinquishing evaluations as a means of assessing certain realities or intervention programmes, both at a public authority and civil society level.

Although there are numerous implications of differing kinds to the introduction of a culture of evaluation, it is clearly important to rule out technocratic, aseptic, worthless assessment systems, as explained by Silverio Barriga (1990: 267-280):

1. Because human action must be contextualized within the framework of a cer- 
1. Porque la acción humana se contextualiza dentro de un proyecto concreto con objetivos intencionales determinados.

2. Porque, de forma directa o indirecta, se participa en la puesta en práctica del proyecto.

3. Porque la evaluación -que es una intervención- puede modificar el contexto de la intervención, y puede producir consecuencias directas e indirectas.

4. Porque de los datos proporcionados por los técnicos se pueden hacer usos contradictorios en todos los sentidos y en todas las perspectivas.

La implantación de una evaluación que tuviera en cuenta estas características supondría la opción por un modelo evaluativo concreto y específico; un modelo que se opondría a un enfoque evaluativo de carácter tecnocrático, burocrático, productivista y cerrado. Por tanto, la dimensión política de la evaluación tiene, inicialmente, dos niveles: en primer lugar se plantea la posibilidad de implantar una cultura de la evaluación para los diferentes subsistemas sociales -educación, servicios sociales, sanidad, cultura, trabajo, etc.-, aunque la cuestión fundamental es si realmente interesa la implementación de una cultura de la evaluación. Y, si interesa, para qué y para quién; $y$, si no interesa, ¿cuáles son las razones de esta negación? Pero, en segundo lugar se trata -una vez resuelta la primera cuestión- de elegir el modelo evaluativo a aplicar para conocer no sólo la calidad de los diferentes servicios, sino también el desarrollo justo, igualitario, no discriminatorio y democrático de los diferentes subsistemas sociales. A estos dos niveles y dimensiones políticas de la evaluación, hay que añadirle la forma de implementación de los diferentes modelos evaluativos, así como la utilización que de los diferentes resultados se puede realizar para tomar las decisiones adecuadas a los objetivos y a las intenciones propuestas. Así, en este contexto, las evaluaciones pueden producir los cambios necesarios de acuerdo con los resultados obtenidos; es decir una reconversión. Sin embargo esta reconversión tiene dos posibles mo- tain project, with specific aims and purposes.

2. Because, directly or indirectly, you are participating in a project's implementation.

3. Because evaluation - something that is, in itself, a form of intervention - can alter the context of an intervention, with ensuing direct or indirect consequences.

4. Because contradictory use can be made of the data provided by experts, in all senses and from all angles.

For these factors to be taken into account, a specific evaluative model must be chosen: that is, a model diametrically opposed to a closed-ended, technocratic, bureaucratic, productivist one. Hence, at a policy level, two initial points must be borne in mind. The first is the potential introduction of a culture of evaluation on different social subscales, at an educational, cultural, health and labour-related and social service level. Having said that, the key question is whether a culture of evaluation is really beneficial and, if it is, what and who is it beneficial for? If, on the other hand, it is not an advantage, then why not? Once this first issue has been settled, a system of evaluation must be chosen, not only to assess the quality of the different services, but also for the fair, equal, non-discriminatory, democratic development of the different social subsystems. In addition to these two policy-related aspects, another point is the way in which the different systems of evaluation are put into practice and the use of the results in decisions tailored to meet certain goals and objectives. In this respect, the obtained results of evaluations can be used to bring about necessary changes or reforms, although these reforms can be applied in two possible ways: through "savage" reforms to the social services, as is currently occurring in many regions and sectors, or "rational" ones.

The introduction of assessment practices is a key methodological factor in rational reforms. Indeed, evaluations must be used as basic in- 
dalidades: por una parte una reconversión "salvaje" de los servicios sociales, tal como se está dando, en muchas comunidades y sectores, en estos momentos; y por otra parte una reconversión "racional" de los servicios sociales.

La reconversión racional deberá tener como elemento metodológico fundamental la implantación de la evaluación; efectivamente, la evaluación debe ser el instrumento básico para que la educación social encuentre su acomodo en la nueva situación. Se trata, en cualquier caso, de consolidar una nueva etapa en la que es importante evaluar los resultados obtenidos, los procesos de implantación llevados a cabo, las metodologías de intervención y de gestión, el análisis del coste-beneficio, etc., con el fin de adaptar los recursos existentes a las nuevas demandas y necesidades, con el fin de optimizar los servicios y los programas existentes, etcétera.

Por tanto, la implantación de una cultura de la evaluación en los momentos actuales no sólo es una necesidad profesional y económica, sino fundamentalmente una opción política fundamental en el proceso de reconversión de los servicios sociales. Una opción que no sólo resulta esencial políticamente, sino también profesionalmente. La no realización de un proceso "racional" de reconversión podría suponer, y de hecho está suponiendo, una desinstitucionalización de los servicios sociales, lo cual iría en detrimento de los sectores sociales más desfavorecidos y la implantación de una "nueva" -"vieja"- concepción benéfico-asistencial de los servicios sociales.

A pesar del desarrollo profesional que ha habido en los últimos años, hay que poner de manifiesto que es necesario conocer, de forma sistemática, lo que se está llevando a cabo, los proyectos de intervención socioeducativa existentes en los diversos ámbitos, los resultados obtenidos, las diversas evaluaciones realizadas en los diversos niveles con el fin de conocer los impactos de los proyectos existentes. Efectivamente, el amplio campo de la Pedagogía Social, en sus diversos ámbitos de actuación, necesita de reflexiones realizadas por los profesionales de la educación social sobre problemas concretos (Orte, Amer, Pascual \&Vaqué, 2014). La necesidad de reflexionar sobre lo que se hace, struments in ensuring that social education finds its place in today's current new scenario. That is, a new stage must be embarked on where outcomes, implementation processes, intervention and management methods, and cost-benefit analyses are all assessed so that existing resources can be adapted to meet new demands and needs with a view to optimizing services and programmes.

In short, a culture of evaluation is not only necessary today in professional and economic terms but also as a major policy option in reforms to the social services. Failure to carry out a "rational" process of reforms might lead to - and indeed it is leading to - the de-institutionalization of the social services, with negative repercussions on more disadvantaged social sectors and a return to the old concept of charity or aid by the social services.

Despite the process of professional development that has taken place in recent years, it is important to gain a systematic overview of what is being done, including existing intervention projects in different fields, the obtained outcomes, and the different evaluations that have been conducted at different levels in order to find out the impacts of existing projects. Given the broad field that social pedagogy covers and its different scopes of activity, specific issues must be taken into consideration by professionals from the field of social education (Orte, Amer, Pascual \& Vaqué, 2014). It is essential to reflect on what is being done, how it is being done, and on the obtained outcomes if we want this to be a robust socio-educational discipline able to combine theory and practice. Clear socio-educational assessment methods must be developed in the field of social pedagogy, based on a planning process designed to meet social and educational needs and demands (Pascual, 2007). Evidently, we have a long pathway ahead of us despite social pedagogy and social education's institutionalization (Janer \& Úcar, 2014). 
cómo se hace o sobre los resultados obtenidos resulta esencial si queremos una disciplina socioeducativa potente y que sea capaz de combinar la teoría y la práctica. Así pues, es evidente que la Pedagogía Social necesita de un desarrollo claro de la evaluación socioeducativa, que se fundamente en un proceso de planificación adecuada a las demandas y necesidades sociales y educativas (Pascual, 2007). En este sentido, resulta evidente que el camino a recorrer es muy largo a pesar del tiempo de institucionalización de la Pedagogía y de la educación social (Janer \& Úcar, 2014).

\section{El insuficiente desarrollo investigador de la Pedagogía Social}

Un análisis de la realidad de la investigación en las distintas universidades españolas en relación al amplio campo de la Pedagogía Social pone de manifiesto, de forma general, una serie de hechos:

a. la debilidad institucional de los diversos grupos de investigación de carácter socioeducativo;

b. la necesidad de posibilitar la continuidad de estos grupos de investigación;

c. la necesaria potenciación de los grupos interuniversitarios de investigación tanto a nivel nacional como a nivel internacional, etc.

No se trata, en cualquier caso, de ignorar lo que se está trabajando desde la perspectiva de la investigación, sino de manifestar todo lo que falta por desarrollar en un campo en el que se necesita trabajar más y mejor. Desde la Pedagogía Social, se debe trabajar a nivel metodológico en una óptica, de triangulación metodológica, que sea capaz de integrar tanto las metodologías de carácter cuantitativo como las metodologías de carácter cualitativo a todos los niveles; se trata, en este sentido, de posibilitar que el enfoque metodológico de la Pedagogía Social, no sólo sea plural y holístico, sino también que destierre la percepción o el dogma, anclado en algunos sectores de esta disciplina, de que sólo se deben utilizar las metodologías cualitativas (Denzin \& Lincoln, 2013). Un planteamiento erróneo que de aplicarse im-

\section{Insufficient research in the field of social pedagogy}

An analysis of the current state of research at different Spanish universities within the broad field of social pedagogy brings to light a series of points:

a. The shaky institutional framework of different socio-educational research groups;

b. The need to foster the survival of these research groups;

c. The need to boost inter-university research groups, both at a national and international level etc.

It is not a question of ignoring what is going on in research circles, but of highlighting everything that still needs to be done in an area in which more concerted, better efforts are needed. Triangulation methods must be applied to work in the field of social pedagogy, integrating both quantitative and qualitative methods at all levels.

Not only must a plural holistic method be used, but it is time to banish the idea or dogma firmly rooted in some sectors of this discipline that only qualitative methods should be used (Denzin \& Lincoln, 2013). This is a misconception that would only hinder the consolidation of social pedagogy. In this context of methodological plurality, of combination of different sources, techniques and quantitative and qualitative methodological approaches it is important to point out a few points. First, we should banish reductionist approaches that tend to exclusively focus on quantitative or qualitative approaches; as social pedagogy needs, by its own nature and characteristics both approaches. In second place it is important to highlight the lack of rigour of some research using qualitative methodologies; this methodology needs rigour, a serious methodological training, an appropriate treatment of the data and well-founded conclusions, going further than intuitions or perceptions lacking evidence.

Some years ago, at a talk presented in an International Symposium on Educational Sociology, educational sociologist Bill Williamson

[ 54 ] MARTÍ XAVIER MARCH CERDÀ, CARMEN ORTE SOCIAS Y LLUÍS BALLESTER BRAGE SIPS - PEDAGOGIA SOCIAL. REVISTA INTERUNIVERSITARIA [1139-1723 (2016) 27, 45-82] TERCERA ÉPOCA 
pediría a la Pedagogía Social su consolidación. En este contexto de la pluralidad metodológica, de la combinación de distintas fuentes, de distintas técnicas y de los enfoques metodológicos cuantitativo y cualitativo, hay que señalar una serie de afirmaciones: en primer lugar hay que desterrar los planteamientos reduccionistas que tienden a poner de manifiesto sólo el uso de la metodología cuantitativa o de la metodología cualitativa; la Pedagogía Social necesita, por su naturaleza y por sus características, de ambos enfoques. Pero, en segundo lugar, hay que poner de manifiesto la falta de rigor de algunas investigaciones de carácter cualitativo; efectivamente el uso de esta metodología necesita de rigor, de una formación metodológica seria, de un tratamiento de los datos adecuado y de unas conclusiones fundamentadas, más allá de las intuiciones o de las percepciones faltas de evidencia.

Ya hace unos cuantos años, el sociólogo de la educación Bill Williamson (1992), en una ponencia presentada en un Simposium Internacional de Sociología de la Educación, se hacía, de forma más o menos ingenua, la siguiente pregunta: ¿para qué sirve el conocimiento que se obtiene de la investigación en sociología de la educación o en cualquier otra disciplina pedagógica? $\bigcirc$ si se prefiere, ¿para quién se realizan los trabajos de investigación educativa?; ¿cuál es la finalidad de la investigación educativa?

Así, de acuerdo con lo planteado y partiendo de la Pedagogía Social, nos podemos formular las siguientes preguntas: ¿Quién selecciona los problemas objeto de la investigación en el ámbito de esta disciplina?, ¿Cómo se seleccionan? ¿Con qué objetivos? ¿Para quien? Las respuestas a estas preguntas no son fáciles: ¿los investigadores? ¿los políticos?, ¿̇los colegios profesionales? ¿las entidades privadas? ¿̇los organismos públicos internacionales, nacionales o regionales? Efectivamente si analizamos el desarrollo investigador de la Pedagogía Social hay que tener en cuenta una serie de elementos de reflexión: ¿por qué se ha desarrollado de forma más importante la temática de la inadaptación social que otras que no se refieren a cuestiones de exclusión social?, ¿̇por qué la cuestión escolar ha tenido un desarrollo poco sustancial en esta disciplina?, ¿por qué los estu-
(1992) posed the following question in a perhaps rather naïve way: what is the knowledge gained from research into educational sociology or any other educational discipline actually for? Or, to put it another way, who are research studies in the field of education for? What purpose do they serve?

Following the same line of thinking but with social pedagogy as our basis, we can, in turn, pose the following questions: who chooses the subjects of research in this field? How are they chosen? What are their goals? For whom are they conducted? The answers to these questions are not easy: researchers, politicians, professional associations, private bodies, or international, national or regional public bodies? If a study is made of the evolution of research in the field of social pedagogy, a series of points for consideration must be taken into account: why has more emphasis been placed on social maladjustment than other issues unrelated to social exclusion? Why have schoolrelated issues received so little attention in this discipline? Why are studies of assessment practices in social education so inconsistent? Why have research results in the field of social education had little relevance on the definition of policies in related areas? Why have studies on assessment processes in social education not been taken further? Why are studies on the subject of maladjusted minors more common than studies on adult education?

Another point for consideration is whether educational research by university researchers conforms more to academic and personal needs than to social, professional or cultural ones. In fact, special reference must be made to the existence in social education of a duality between researchers and academics' interests and society's own needs. This is a delicate issue that must be faced if both interests are to be brought in line in order to ensure the development of social pedagogy. Nonetheless, this is not the only dichotomy that can be found in socio-educational research. There is also a dichotomy or duality between basic and applied socio-educational research, and between socio-educa- 
dios de evaluación en la educación social son poco consistentes?, ¿por qué los resultados de la investigación en educación social han tenido escasa relevancia en la definición de las políticas sobre los diversos campos de dicha disciplina?, ¿por qué los estudios sobre la evaluación en educación social han sido poco desarrollados?, ¿’por qué los estudios sobre los menores en proceso de inadaptación social son más frecuentes que los estudios sobre la educación de las personas mayores?

Además, es necesario plantearse si la investigación educativa que llevan a cabo los investigadores universitarios está más en relación con necesidades académicas y personales que en relación a necesidades sociales, profesionales y culturales. En este contexto, es necesario hacer una referencia específica a la existencia de una dualidad entre los intereses de los investigadores, de los académicos, y los intereses, las necesidades de la sociedad desde la perspectiva de la educación social. Efectivamente, se trata de una cuestión delicada que alguna vez hay que plantear, y a la que es necesario dar una respuesta si queremos que ambos intereses coincidan para el desarrollo de la Pedagogía Social. Pero, ésta no es la única dicotomía en la investigación en educación social; nos referimos a la dicotomía, a la dualidad existente entre la investigación socioeducativa básica y la investigación socioeducativa aplicada. También, hay que referirse a la dicotomía, la dualidad existente entre la investigación en educación social y la intervención socioeducativa. Efectivamente, resulta evidente que uno de los elementos básicos de la Pedagogía Social es, sin duda alguna, su doble componente en relación a la investigación y a la acción; es una disciplina para conocer y para actuar; $y$ este doble objetivo es fundamental que se tenga en cuenta en el momento de llevar a cabo cualquier tipo de proyecto de investigación.

\section{La evidencia científica como fundamento de la acción socioeducativa}

El progreso de la Pedagogía Social sólo puede llevarse a cabo a partir de los planteamientos anteriormente desarrollados: 1) Es necesario el desarrollo de la investigación socioeducativa desde tional research and interventions. One of the basic characteristics of social pedagogy is clearly its dual dimension in terms of research or knowledge and action, and this dual aim must be taken into account when any kind of research study is conducted.

\section{Scientific evidence as a basis for socio- educational action}

Progress in Social Education can only be made based on ideas expanded upon previously: 1) Socio-educational research needs to be developed with rigour, diversity and methodological triangulation, using quantitative and grounded qualitative methodology, etc. 2) Socio-educational assessment needs to be developed at its various levels and with different conceptual approaches. Therefore, the development of Social Education only makes sense if it is done not just based on a wellgrounded theoretical concept but also from a rigorous methodological standpoint. The era of speculation, of reflection without information, of educational essentialism, no longer makes sense, not only from the point of view of effectiveness but also from an evidencebased approach to social and socio-educational change (Forés \& Novella, 2013).

From this standpoint, as set out in the introduction, we uphold the idea that socio-educational interventions must be based on scientific evidence. To us, this has to be the foundation stone on which Social Education is built and rebuilt. This should be the route map laid out by social and educational challenges to which science should give effective responses at individual and communal level. Therefore, as propounded by Sánchez-Meca, Marín Martínez \& López-López (2011, 95):

"Professional practice should be based on the best scientific evidence. This fundamental premise should be applied to any professional field and, as such, to the field of psychosocial intervention. Professionals in this field should decide which programme, treatment or intervention to use depending on the

[56] MARTí XAVIER MARCH CERDÀ, CARMEN ORTE SOCIAS Y LLUÍS BALLESTER BRAGE SIPS - PEDAGOGIA SOCIAL. REVISTA INTERUNIVERSITARIA [1139-1723 (2016) 27, 45-82] TERCERA ÉPOCA 
el rigor, la pluralidad, la diversidad y la triangulación metodológica, desde la metodología cuantitativa, desde la metodología cualitativa fundamentada, etc. 2) Es necesario el desarrollo de la evaluación socioeducativa en sus diversos niveles y desde planteamientos conceptuales distintos. Por tanto, el desarrollo de la Pedagogía Social sólo tiene sentido si se realiza, no sólo a partir de una concepción teórica bien fundamentada, sino también desde un planteamiento metodológico riguroso. La época de la especulación, de la reflexión sin datos, del esencialismo pedagógico ya no tiene sentido. Y no sólo desde un enfoque de la eficacia, sino desde una planteamiento de cambio social, de cambio socioeducativo basado en evidencias (Forés \& Novella, 2013).

Desde esta perspectiva, tal como hemos planteado en la introducción, reivindicamos la idea de que las intervenciones socioeducativas deben estar basadas sobre las evidencias científicas. $Y$ para nosotros éste debe ser el hilo conductor sobre el que la Pedagogía Social se debe construir y reconstruir. Ésta debe ser la hoja de ruta que los retos sociales y educativos plantean y a los que la ciencia de la educación social debe dar respuestas eficaces a nivel individual y a nivel comunitario. Así, tal como plantean Sánchez-Meca, Marín-Martínez \& López-López (2011, 95):

“La práctica profesional debería estar basada en las mayores evidencias científicas. Esta premisa fundamental debería aplicarse a cualquier ámbito profesional y, como tal, al campo de la intervención psicosocial. Los profesionales de este campo deberían decidir qué programa, tratamiento o intervención aplicar en función de las evidencias alcanzadas en estudios evaluativos empíricos debidamente diseñados e implementados. Además, las políticas sociales, educativas y sanitarias deberían también decidirse tomando en consideración la evidencia científica acumulada cómo mejor tratar o prevenir los problemas sociosanitarios. Con este propósito ha surgido el enfoque de la Práctica basada en la Evidencia, como una herramienta dirigida a lograr que los programas tratamientos e intervenciones que se apliquen en la prác- evidence arising in empirical assessment studies, properly designed and implemented. Furthermore, social, education and health policies should also be adopted taking accumulated scientific evidence on the best way to treat or prevent social and health problems into consideration. With this aim, focus on Evidence-based Practice has emerged, as a tool aimed at achieving treatment and intervention programmes applied in routine professional practice that are based on the best scientific proof or evidence."

Given this context, the authors consider that psycho-social intervention professionals should have the appropriate expertise to be able to apply the Evidence-based Psycho-social Intervention Focus. A focus that should be systematically reviewed by empirical studies, which should offer a panoramic view of the most effective programmes for resolving, or preventing a psycho-social or socio-educational problem. In this context, such an in-depth review should be carried out using rigorous systematic studies and/or meta-analyses on the problems to be resolved.

If meta-analysis is chosen, what steps does it take? Before addressing this question, within the framework of evidence-based socio-educational or psychosocial intervention, it should be taken into account that, as stated previously, Social Education, both on its research side and its assessment side, suffers from a lack of solid evaluation studies and socio-educational research, even ones with contradictory or differing results. This makes meta-analysis more difficult, giving Social Education the challenge of responding to this shortfall so that evidence-based socio-educational intervention has the opportunity to develop.

Overall, and in agreement with the abovementioned authors, the steps for this possible, and necessary, meta-analysis are as follows: 1. Formulate the problem; 2. Seek out research; 3. Classify the research; 4. Calculate the size of the effect; 5 . Statistical analysis and interpretation; 6. Publication. It is, therefore, a series of methodological stages 
tica profesional rutinaria sean aquéllos que estén basados en los mejores evidencias o pruebas científicas."

Estos autores, en el contexto planteado, consideran que los profesionales de la intervención psicosocial deberían tener los conocimientos adecuados para aplicar el Enfoque de la Intervención Psicosocial basada en la Evidencia. Un enfoque que debe tener revisiones sistemáticas de los estudios empíricos, que debe ofrecer una panorámica sobre los programas más eficaces para resolver o prevenir un problema psicosocial o socioeducativo. En este contexto, la realización de esta revisión en profundidad debe llevarse a cabo, entre otros, a través de estudios sistemáticos rigurosos y/o de un metaanálisis sobre la problemática a resolver.

En el caso de elegir el meta-análisis ¿̇cuáles son las fases del mismo? Antes de abordar esta cuestión, en el marco de la intervención socioeducativa o psicosocial basada en la evidencia, hay que tener en cuenta que la Pedagogía Social, tanto en su vertiente de investigación como en su vertiente evaluativa, adolece, tal como se ha puesto de manifiesto anteriormente, de estudios evaluativos y de investigación socioeducativos, sólidos, aunque sea con resultados contradictorios o diversos. Y ello dificulta la realización de este meta-análisis; por tanto, la Pedagogía Social tiene el reto de dar respuesta a dicha carencia, para que la intervención socioeducativa sobre la evidencia, tenga posibilidades de desarrollo.

Con todo, y de acuerdo con los autores mencionados, hay que poner de manifiesto que las fases de este posible y necesario meta-análisis son las siguientes: 1. Formulación del problema; 2. Búsqueda de estudios. 3. Codificación de los estudios; 4. Cálculo del tamaño del efecto; 5. Análisis estadístico e interpretación; 6. Publicación. Se trata, pues, de una serie de fases de carácter metodológico que necesitan, para su eficacia, de la existencia de estudios basados en la investigación y evaluación. Por tanto, el necesario meta-análisis necesita tanto del desarrollo de investigaciones socioeducativas sólidas, como de evaluaciones sobre los programas de intervención socioeducativa. En todo caso which, to be effective, need research- and assessment-based studies to exist. For this reason, the meta-analysis required needs development of solid socio-educational research as well as assessments of socio-educational invention programmes. At any event, this analysis methodology is a good choice for taking the effectiveness of socio-educational interventions into account from all angles. In this respect, Sánchez-Meca, Marín-Martínez \& López-López $(2011,105)$ say the following:

"There is no doubt that meta-analyses of the effectiveness of interventions in the psycho-social field are providing highly useful information for them to be put into practice by the professionals who have to make decisions on a day-to-day basis about how to intervene or treat the social, educational and psychological problems which are part of their daily work."

Within this perspective, research undertaken by the Grupo de Investigación y Formación Educativa y Social (GIFES, Social and Educational Research Group), from the Department of Education and Didactics of the Balearic University is an example of a research group that works with this perspective of evidence-based programs (Orte, Touza \& Ballester, 2007). The question as to the effectiveness of preventive work, measured in terms of consistent change in a set of relevant factors, comes as a result of a concern on behalf of technicians and policy makers regarding most preventive programs. In the research conducted by the Social and Educational Training and Research Group (GIFES-UIB) concerning the implementation of the Family Competence Program (Kumpfer, 1998) for the Spanish population, this was one of our concerns (Orte, Ballester \& March, 2013).

Which are the foundations of the Fam.ily Competence Program? The accumulation, for a few decades now, of studies that relate parental behaviours with the social, emotional and psychological development of their children (for instance, Baumrind, 1971; Kochanska, Murray \& Coy, 1997; Lila, Musitu \& Buelga, 2001; Musitu \& García, 2004; Lila \& Gracia,

[ 58 ] MARTÍ XAVIER MARCH CERDÀ, CARMEN ORTE SOCIAS Y LLUÍS BALLESTER BRAGE SIPS - PEDAGOGIA SOCIAL. REVISTA INTERUNIVERSITARIA [1139-1723 (2016) 27, 45-82] TERCERA ÉPOCA 
esta metodología de análisis es una buena opción para tomar en consideración la eficacia de las intervenciones socioeducativas en todas sus dimensiones. Sánchez-Meca, Marín-Martínez \& López-López $(2011,105)$ dicen lo siguiente, al respecto de esta cuestión:

"No cabe duda de que los meta-análisis sobre la eficacia de intervenciones en el ámbito psicosocial están aportando una información de gran utilidad para su puesta en práctica por los profesionales que tienen que tomar decisiones día a día acerca de cómo intervenir o tratar los problemas sociales, educativos y psicológicos que forman parte de su quehacer cotidiano."

En esta misma óptica, como uno de los ejemplos de grupos de investigación que trabajan utilizando dicha perspectiva, los trabajos de investigación del Grupo de Investigación y Formación Educativa y Social (GIFES-UIB) del Departamento de Pedagogía y Didácticas Específicas de la UIB se enmarcan dentro del contexto fundamentado en los programas eficaces (Orte, Touza \& Ballester, 2007). Así, la pregunta sobre la eficacia del trabajo preventivo, medido en términos de cambio consistente, en un conjunto de factores relevantes, responde a una preocupación de los técnicos y de los políticos de la mayoría de los programas preventivos. De forma concreta, las investigaciones de GIFESUIB, sobre la validación del Programa de Competencia Familiar (Kumpfer, 1998) para población española, ha sido una de nuestras preocupaciones (Orte, Ballester \& March, 2013).

¿Cuál es la fundamentación de este Programa de Competencia Familiar? La acumulación, desde hace ya algunas décadas, de investigaciones que relacionan las conductas parentales con el desarrollo social, emocional y psicológico de los hijos (por ejemplo, Baumrind, 1971; Kochanska, Murray \& Coy, 1997; Lila, Musitu \& Buelga, 2001; Musitu \& García, 2004; Lila \& Gracia, 2005) parece no dejar lugar a dudas acerca de algunas de las consecuencias de esta relación: los padres con adecuadas competencias parentales, los padres afectivos, que responden ante las necesidades de sus hijos, que les permiten participar activamente en el establecimiento de las normas familiares y que uti-
2005) seems to leave no room for doubt as to some of the consequences of this relationship: parents with appropriate parenting skills, affective parents, who respond to the needs of their children, who allow them to participate actively in the establishment of family rules and who use positive discipline options, achieve independent, sociable, cooperative, self-confident children.

The Family Competence Program (FCP) is an adaptation of the Strengthening Families Program (SFP) (Kumpfer \& DeMarsh, 1985; Kumpfer, DeMarsh \& Child, 1989), which is a selective multicomponent risk factor prevention program whose original design was developed to reduce the influence of family risk factors in the sons and daughters of substance abusing people whilst strengthening protection factors, with the purpose of increasing their resilience to substance abuse and other possible problems. It is considered a model program in the classification made by the Substance Abuse and Mental Health Services Administration (SAMHSA), whose quality criteria include fidelity in the intervention, assessment of the process, measurements of the outcome of a change in behaviours, and the validity of the measuring procedures.

Originally, the concept of socio-educational work was applied as a generic label, which identified the intervention as having a dual focus and little else. Over time, socioeducational interventions have developed into a much more sophisticated approach, including systemic and relational approaches, at a non-clinical level. Differences between these and so-called "family therapies" have grown, not only due to the differentiated approach, but also because of the formalization of programs working with families, as well as the development of very detailed assessment research. Within the framework of socio-educational work, and as a result of the systemic and relational approach, socio-educational interventions have been developed with the family. The methodologies implemented, initially influenced by cognitive- behavioural and systemic approaches, allowed significant 
lizan opciones de disciplina positiva, consiguen hijos independientes, sociables, cooperativos y que confían en sí mismos.

El Programa de Competencia Familiar (PCF) es una adaptación del Strengthening Families Program (SFP) (Kumpfer \& DeMarsh, 1985; Kumpfer, DeMarsh \& Child, 1989), que es un programa de prevención de factores de riesgo multicomponente de tipo selectivo cuyo diseño original fue desarrollado para reducir la influencia de factores de riesgo familiares en los hijos e hijas de personas drogodependientes, al mismo tiempo que se refuerzan los factores de protección, con la finalidad de aumentar su resiliencia ante el consumo y otros posibles problemas de comportamiento o conductas problema. Está considerado como un programa modelo en la clasificación hecha por el Sustance Abuse and Mental Health Services Administration (SAMHSA), entre cuyos criterios de calidad se contemplan la fidelidad en la intervención, la evaluación del proceso, medidas de resultado del cambio de conductas y la validez de los procedimientos de medida.

En sus orígenes, el concepto de trabajo socioeducativo se aplicaba como una etiqueta genérica que identificaba la intervención como doblemente enfocada y poco más. Con el tiempo, las intervenciones socioeducativas se han desarrollado como un enfoque mucho más sofisticado, incluyendo planteamientos sistémicos y relacionales, en un nivel no clínico. Las metodologías aplicadas, influidas inicialmente por planteamientos cognitivo-conductuales y sistémicos, han permitido un importante avance en los modelos de trabajo basados en la evidencia empírica. En este contexto y teniendo en cuenta los enfoques de los programas de prevención de drogas y/o conductas problemáticas basados en la evidencia científica, se desarrolla el enfoque de competencia familiar, como un enfoque educativo, centrado en el conjunto de la familia y desarrollado mediante programas escritos, es decir con un curriculum muy desarrollado en función de los objetivos de cambio que se pretende alcanzar, entre los cuales destaca el Strengthening Family Program (SFP), Programa de Competencia Familiar (PCF) en Es- progress to be made in work models based on empirical evidence. The family competence approach was developed in this context, as a not-directly-clinical approach, focusing on the family as a whole and carried out using written programs, one of the most outstanding of which is the Strengthening Family Program (SFP) - the Family Competence Program (PCF) in Spain (Orte et al, 2008a) - structured in accordance with criteria for the most effective intervention programs.

The implementations conducted by GIFES focused on drug prevention programs, especially Proyecto Hombre in Spain, as well as on primary care social services and child protection services. This study focuses on controlled implementations in social services between 2009 and 2013. The FCP has been through three design and research stages in Spain:

- Initial experimentation: 2005. Transversal design based on implementations of 14 sessions and pre- and post- measurements. - Generalised implementations in drug prevention services, primary care social services and child protection services, based on the corrections introduced after initial experimentation: 2006-2011. Transversal design based on implementations of 14 sessions and pre- and post- measurements. - Longitudinal design: 2011-2013, currently in process. The analyses conducted are complemented with a two-year follow-up of the participating families. In 2011 we collected data concerning the families that finished in 2009; in 2012 we are collecting the data on the families that finished in 2010; in 2013 we will collect data concerning the families that finished in 2011, the last generalised implementations.

[ 60 ] MARTÍ XAVIER MARCH CERDÀ, CARMEN ORTE SOCIAS Y LLUÍS BALLESTER BRAGE SIPS - PEDAGOGIA SOCIAL. REVISTA INTERUNIVERSITARIA [1139-1723 (2016) 27, 45-82] TERCERA ÉPOCA 
paña (Orte, 2008), estructurado de acuerdo a los criterios para los programas de intervención más eficaces.

Es pues en el marco de los programas basados en la evidencia científica en el que se han llevado a cabo las aplicaciones realizadas por GIFES, la cuales se han centrado en programas de prevención de drogas, en especial los del Proyecto Hombre en España, así como en los servicios sociales de atención primaria y servicios de protección de menores. Al respecto de los trabajos sobre prevención familiar, GIFES se ha centrado en las aplicaciones controladas en los servicios sociales entre 2009 y 2013 . El diseño e investigación del PCF tiene tres etapas en España:

- Experimentación inicial: 2005. Diseño transversal basado en aplicaciones de 14 sesiones y medidas previas y posteriores.

- Aplicaciones generalizadas a servicios de prevención de drogas, a servicios sociales de atención primaria y a servicios de protección de menores, a partir de las correcciones introducidas después de la experimentación inicial: 2006-2011. Diseño transversal basado en aplicaciones de 14 sesiones y medidas previas y posteriores.

- Diseño longitudinal: 2011-2013. Se completan los análisis realizados con seguimiento a dos años de las familias participantes. En 2011 se recogen datos de las familias que finalizaron en 2009; en 2012 se toman datos de las familias que finalizaron en 2010; en 2013 se toman datos de las familias que finalizaron en 2011 las últimas aplicaciones generalizadas.

La adaptación realizada por GIFES (Orte \& GIFES, 2005a, 2005b; Orte, Touza \& Ballester, 2007), ha procurado alcanzar criterios de calidad, de forma que en la validación del PCF se ha utilizado un diseño de evaluación quasi-experimental pretest-postest con grupos de control, complementado por medidas de proceso generadas a partir de evaluaciones proceso-resultados. Las evaluaciones realizadas se han centrado en los resultados y en los procesos desarrollados.

En cualquier caso es evidente que la Peda-
The adaptation carried out by GIFES (Orte \& GIFES, 2005a, 2005b; Orte, Touza \& Ballester, 2007) sought to meet quality criteria, therefore in the FCP a pre-test/posttest assessment was used along with control groups, complemented by process measurements produced from the process-outcome assessments. The assessments conducted focused on the outcomes and on the processes carried out. In the study presented here, some of the most outstanding processes are related to the outcomes obtained by the families. Of the many implementation processes involved in a preventive program, we chose the ones related to the family competence approach methodology characterised by the FCP. As far as the change observed in the participants is concerned, we selected the factors that report change in the families as a whole.

In any case it is evident that Social Education must, if it wants to be competitive, effective, credible, rigorous and well-grounded, continue along the route of evidence and effectiveness. Otherwise an essentialist, theoretical Educational model will be followed which is far removed from socio-educational problems. 
gogía Social debe, si quiere ser competitiva, eficaz, creíble, rigurosa y fundamentada, continuar por esta línea de las evidencias y de la eficacia. Lo contrario es seguir con un modelo de Pedagogía esencialista, teoricista y alejada de los problemas socioeducativos.

\section{La Pedagogía Social en la Universidad}

Las investigaciones desarrolladas por GIFESUIB y otros grupos de investigación universitarios, se caracterizan por cuatro rasgos comunes que les permiten acreditar sus aportaciones, en el contexto de la investigación socioeducativa:

- se trata de investigaciones válidas, con diseños metodológicos sólidos, profundizando en el análisis de los procesos y los resultados;

- investigaciones basadas en la transparencia de los datos, contrastadas en contextos diversos: congresos, revistas rigurosas, etc.

- se desarrollan a partir de la articulación con servicios de la administración, tercer sector social y empresas de iniciativa social, así como de las necesidades sociales y educativas identificadas en la comunidad;

- se desarrollan desde contextos universitarios, permitiendo vincular la investigación al desarrollo conceptual de la pedagogía social; pero también, enriqueciendo los procesos de formación de los profesionales de dicho ámbito (pedagogía, educación social).

Los grupos de investigación que, desde hace unos años, trabajan desde este enfoque, se han creado y desarrollado en la universidad, intentando superar las limitaciones apuntadas anteriormente. Uno de los factores que han permitido dicho desarrollo ha sido la creación, en los veinte últimos años, de los estudios universitarios de Educación Social en España, a partir del Real Decreto 1420/1991 de 30 de agosto (BOE 10 de octubre) (Ruiz, 2003). La Pedagogía Social, como disciplina, debe aprovechar la oportunidad que se le ofrece con dichos estudios. Los estudios de Educación Social ofrecen un contexto de reflexión y análisis, así como unas oportunidades de conexión social, que deben ser aprovechadas en el sentido del enfoque defendido en las secciones anteriores del

\section{Social Pedagogy at the University}

Research carried out by GIFES-UIB and other university research groups is marked by four common traits enabling contributions to be accredited within the context of socio-educational research:

- it is valid research with solid methodological designs, analysing processes and results in depth;

- the research is based on transparency of the information and verified in various contexts: conferences, rigorous reviews, etc.

- it is carried out based on linkage with government services, the third social sector and social initiative enterprises, alongside the social and education needs identified in the community;

- it is carried out within university contexts, enabling research to be linked with the conceptual development of social pedagogy, but, at the same time, enriching the educational process for professionals in the field (teaching and social education).

Research groups, which have been working for some years with this focus, were created and developed at the university with the intention of overcoming the limitations noted previously. One of the factors enabling this development was the creation, over the last twenty years, of university courses in Social Education in Spain, via Royal Decree 1420/1991, of 30 August (Official State Gazette 10 October) (Ruiz, 2003). Social Pedagogy, as a discipline, should make the most of the opportunity offered by these courses. Social Education studies offer a context for reflection and analysis along with opportunities for social connection, which should be taken advantage of as the focus defended in previous sections of the article: improving the quality of Welfare State services (social, educational and cultural, etc), introducing a culture of quality assessment and carrying out socio-educational research. All of this should be connected to improvements in training professionals along with improvements to the social insertion of those professionals.

[ 62 ] MARTÍ XAVIER MARCH CERDÀ, CARMEN ORTE SOCIAS Y LLUÍS BALLESTER BRAGE SIPS - PEDAGOGIA SOCIAL. REVISTA INTERUNIVERSITARIA [1139-1723 (2016) 27, 45-82] TERCERA ÉPOCA 
artículo: mejorar la calidad de los servicios del Estado del Bienestar (sociales, educativos, culturales, etc.), implantar una cultura de la evaluación de calidad, desarrollar investigaciones socioeducativas. Todo ello, conectado con la mejora de la formación de los profesionales, así como con la mejora de la inserción social de dichos profesionales.

Para completar el análisis, se ha desarrollado una limitada investigación sobre los estudios universitarios de educación social en el Estado. La metodología de la investigación es evaluativa, con un planteamiento descriptivo sin la pretensión inferencial. El objetivo de la misma es comprobar las características definitorias de la oferta actual de estudios de Educación Social, mediante una revisión de una muestra de los centros de formación.

\subsection{Muestra}

En esta investigación, centrada en los estudios de Educación Social, se considera que el universo de referencia está configurado por el conjunto de los centros universitarios en los que se ofrecen estudios de educación social en España, en total 34 centros con 2.617 plazas ofertadas cada curso académico'. La muestra realizada es de tipo estructural (Ballester, Nadal \& Amer, 2014), seleccionando 11 universidades (32,35\% de los centros) que desarrollan los estudios en tres zonas del Estado: el norte del país, el centro y el sur, así como la zona mediterránea.

Cuadro 1. Universidades participantes

\begin{tabular}{|l|l|}
\hline \multirow{4}{*}{ Zona Norte } & Universidad de Santiago de Compostela \\
\cline { 2 - 2 } & Universidad de Vigo \\
\cline { 2 - 2 } & Universidade da Coruña \\
\hline \multirow{4}{*}{$\begin{array}{l}\text { Zona centro } \\
\text { y sur }\end{array}$} & Universidad Complutense de Madrid \\
\cline { 2 - 2 } & Universidad de Castilla-La Mancha (UCLM) \\
\cline { 2 - 2 } & Universidad de Las Palmas de Gran Canaria \\
\hline \multirow{4}{*}{$\begin{array}{l}\text { Zona } \\
\text { mediterrá- } \\
\text { nea }\end{array}$} & Universitat de Barcelona \\
\cline { 2 - 3 } & Universitat de Girona \\
\cline { 2 - 3 } & Universitat de les Illes Balears \\
\cline { 2 - 3 } & Universitat Rovira i Virgili \\
\hline
\end{tabular}

To complete the analysis, limited research has been carried out on university courses in social education in Spain. The methodology for the research is evaluative with a descriptive bias without inferential pretence. Its aim is to test the defining features of the courses in Social Education that are currently on offer by reviewing a sample of training centres.

\subsection{Sample}

This research, centred on Social Education studies, considers that the sphere of reference is made up of the group of universities offering social education courses in Spain, 34 centers in total with 2,617 seats offered every academic year ${ }^{1}$. The sample taken is structural in nature (Ballester, Nadal \& Amer, 2014), selecting 11 universities (32.35\% of the centers) running these courses in three areas of Spain: the North of the country, Central and Southern Spain and the Mediterranean area.

Chart 1. Participating Universities

\begin{tabular}{|l|l|}
\hline \multirow{4}{*}{$\begin{array}{l}\text { Northern } \\
\text { Area }\end{array}$} & Santiago de Compostela University \\
\cline { 2 - 2 } & Vigo University \\
\cline { 2 - 2 } $\begin{array}{l}\text { Central and } \\
\text { Southern } \\
\text { Area }\end{array}$ & Universidade da Coruña \\
\cline { 2 - 2 } & University of Castile-La Mancha (UCLM) \\
\cline { 2 - 2 } & University of Las Palmas de Gran Canaria \\
\hline \multirow{4}{*}{$\begin{array}{l}\text { Mediterra- } \\
\text { nean Area }\end{array}$} & Barcelona University \\
\cline { 2 - 2 } & Girona University \\
\cline { 2 - 2 } & Catalonia Open University \\
\cline { 2 - 2 } & Rovira i Virgili University \\
\hline
\end{tabular}


Se realizaron invitaciones a todos los departamentos del Estado que ofrecen la titulación, completando la muestra cuando se consiguió completar el número mínimo de centros por zona (3).

\subsection{Variables de análisis}

Las variables sobre las que se estructuró la recogida de información en esta investigación fueron:

- Estructura de la oferta.

- Características de la formación ofrecida.

- Resultados formativos.

Los datos sobre las dos primeras variables se pudieron detallar sin demasiadas dificultades, sin embargo, los datos sobre los resultados formativos no son concluyentes, por lo que se ha prescindido de los mismos en la presentación que se realizará a continuación.

\subsection{Metodología y fuentes de información}

La recogida de la información se ha realizado con dos metodologías complementarias: un cuestionario, acordado en el contexto de la SIPS, de respuesta sobre web; una revisión de las web de las propias universidades que ofrecen estudios de educación social. Los informantes seleccionados fueron los responsables de las titulaciones, contestando mayoritariamente los jefes de estudio de las titulaciones.

\subsection{Análisis y tratamiento de la información}

El análisis se realizó en dos fases complementarias. Primero, las preguntas cerradas se han tratado con SPSS. Los registros digitales de las preguntas abiertas fueron tratados con el programa NVIVO.

\subsection{Resultados de la investigación}

Por lo que se refiere al tipo de enseñanza (tabla 1), como sabemos, la gran mayoría de la oferta es presencial, existiendo algunas experiencias de formación a distancia. En la tabla se considera exclusivamente la oferta a distancia de la UOC,
Invitations were made to all the departments in Spain offering the qualification, with the sample being complete when a minimum number of universities per area (3) was obtained.

\subsection{Analysis variables}

The variables on which data capture was structured in this research were:

- Structure of the offer.

- Features of the training offered.

- Educational results.

The data on the first two variables could be detailed without much difficulty. However the data on educational results were not conclusive and therefore have been excluded from the presentation below.

\subsection{Methodology and sources of information}

Data capture was carried out using two complementary methodologies: a questionnaire, within the SIPS context, to be answered over the internet and a review of the web sites of the universities offering social education courses. The selected informants were those in charge of the courses, with answers mainly being given by the directors of studies on the courses.

\subsection{Data analysis and processing}

Analysis was made in two complementary stages. Firstly, the closed questions were processed through SPSS and then the digital records of the open questions were processed using the NVIVO program.

\subsection{Results of the research}

With reference to the type of teaching (table 1), as we know, the vast majority of the offer is classroom-based, with some distance learning courses being available. The table exclusively includes distance learning course given by Cat- 
Tabla 1. Tipo de enseñanza según zonas del Estado

\begin{tabular}{|l|c|c|c|c|c|}
\hline \multicolumn{2}{|c|}{} & \multicolumn{4}{c|}{ Zonas del Estado } \\
\hline \multicolumn{2}{|l|}{ Tipo de enseñanza } & Centro y sur & Norte y oeste & Mediterráneo & Total \\
\hline \multirow{2}{*}{ On line o a distancia } & Frecuencia & 0 & 0 & 1 & 1 \\
\cline { 2 - 6 } & $\%$ & $0,0 \%$ & $0,0 \%$ & $20,0 \%$ & $9,1 \%$ \\
\hline \multirow{2}{*}{ Presencial } & Frecuencia & 3 & 3 & 4 & 10 \\
\cline { 2 - 6 } & $\%$ & $100,0 \%$ & $100,0 \%$ & $80,0 \%$ & $90,9 \%$ \\
\hline \multirow{2}{*}{ TOTAL } & Frecuencia & 3 & 3 & 5 & 11 \\
\cline { 2 - 6 } & $\%$ & $100,0 \%$ & $100,0 \%$ & $100,0 \%$ & $100,0 \%$ \\
\hline
\end{tabular}

Table 1. Type of teaching by areas in Spain

\begin{tabular}{|c|c|c|c|c|c|}
\hline & & \multicolumn{4}{|c|}{ Areas of Spain } \\
\hline \multicolumn{2}{|l|}{ Type of teaching } & Central and south & North and east & Mediterranean & Total \\
\hline \multirow{2}{*}{ On line or distance } & Incidence & $\mathrm{O}$ & O & 1 & 1 \\
\hline & $\%$ & $0.0 \%$ & $0.0 \%$ & $20.0 \%$ & $9.1 \%$ \\
\hline \multirow{2}{*}{ Classroom-based } & Incidence & 3 & 3 & 4 & 10 \\
\hline & $\%$ & $100.0 \%$ & $100.0 \%$ & $80.0 \%$ & $90.9 \%$ \\
\hline \multirow{2}{*}{ TOTAL } & Incidence & 3 & 3 & 5 & 11 \\
\hline & $\%$ & $100.0 \%$ & $100.0 \%$ & $100.0 \%$ & $100.0 \%$ \\
\hline
\end{tabular}

Tabla 2. Año que se empezó a impartir la Diplomatura según zonas del Estado

\begin{tabular}{|l|c|c|c|c|c|}
\hline \multicolumn{5}{|c|}{ Zonas del Estado } \\
\hline \multirow{2}{*}{ Año que se empezó a impartir la Diplomatura } & Centro y sur & Norte y oeste & Mediterráneo & Total \\
\hline \multirow{2}{*}{ Antes de 1995 } & Frecuencia & 1 & 2 & 4 & 7 \\
\cline { 2 - 6 } & $\%$ & $66,7 \%$ & $100,0 \%$ & $100,0 \%$ & $90,9 \%$ \\
\hline \multirow{2}{*}{ 1995-1999 } & Frecuencia & 2 & 1 & 1 & 4 \\
\hline \multirow{2}{*}{ TOTAL } & Frecuencia & $33,3 \%$ & $0,0 \%$ & $0,0 \%$ & $9,1 \%$ \\
\cline { 2 - 6 } & $\%$ & $100,0 \%$ & $100,0 \%$ & $100,0 \%$ & 11 \\
\hline
\end{tabular}

Table 2. Year when the Diploma began to be taught according to area in Spain

\begin{tabular}{|l|c|c|c|c|c|}
\hline \multicolumn{5}{|c|}{ Areas of Spain } \\
\hline Year when the Diploma began to be taught & Central and south & North and east & Mediterranean & Total \\
\hline \multirow{2}{*}{ Before 1995 } & Incidence & 1 & 2 & 4 & 7 \\
\cline { 2 - 6 } & $\%$ & $66.7 \%$ & $100.0 \%$ & $100.0 \%$ & $90.9 \%$ \\
\hline \multirow{2}{*}{$1995-1999$} & Incidence & 2 & 1 & 1 & 4 \\
\hline \multirow{2}{*}{ TOTAL } & Incidence & $33.3 \%$ & $0.0 \%$ & $0.0 \%$ & $9.1 \%$ \\
\cline { 2 - 6 } & $\%$ & $100.0 \%$ & $100.0 \%$ & $100.0 \%$ & $100.0 \%$ \\
\hline
\end{tabular}


Tabla 3. Año de inicio del título de Grado según zonas del Estado

\begin{tabular}{|l|c|c|c|c|c|}
\hline \multicolumn{4}{|c}{} & \multicolumn{2}{c|}{ Zonas del Estado } \\
\hline \multirow{2}{*}{ Año de inicio del título de Grado } & Centro y sur & Norte y oeste & Mediterráneo & Total \\
\hline \multirow{2}{*}{2009} & Frecuencia & 2 & 3 & 5 & 10 \\
\cline { 2 - 6 } & $\%$ & $66,7 \%$ & $100,0 \%$ & $100,0 \%$ & $90,9 \%$ \\
\hline \multirow{2}{*}{2010} & Frecuencia & 1 & 0 & 0 & 1 \\
\hline \multirow{2}{*}{ TOTAL } & $\%$ & $33,3 \%$ & $0,0 \%$ & $0,0 \%$ & $9,1 \%$ \\
\cline { 2 - 6 } & Frecuencia & 3 & 3 & 5 & 11 \\
\hline
\end{tabular}

Table 3. Year when the Degree began to be taught according to area in Spain

\begin{tabular}{|l|c|c|c|c|c|}
\hline \multicolumn{5}{|c|}{ Areas of Spain } \\
\hline Year when the DEGREE began to be taught & Central and south & North and east & Mediterranean & Total \\
\hline \multirow{2}{*}{2009} & Incidence & 2 & 3 & 5 & 10 \\
\cline { 2 - 6 } & $\%$ & $66.7 \%$ & $100.0 \%$ & $100.0 \%$ & $90.9 \%$ \\
\hline \multirow{2}{*}{2010} & Incidence & 1 & 0 & 0 & 1 \\
\hline \multirow{2}{*}{ TOTAL } & $\%$ & $33.3 \%$ & $0.0 \%$ & $0.0 \%$ & $9.1 \%$ \\
\cline { 2 - 6 } & Incidence & 3 & 3 & 5 & 11 \\
\hline
\end{tabular}

pero debe tenerse presente que la UIB ofrece una modalidad completa a distancia. En cualquier caso, hay que tener en cuenta que la mayor presencia de oferta a distancia en el área mediterránea no puede hacernos olvidar que la UNED ofrece dicha formación desde Madrid.

La mayoría de la oferta estudiada se desarrolló inmediatamente después de ser aprobada la titulación (tabla 2), aunque los ritmos fueron diferentes en el conjunto del Estado, siendo más lento el desarrollo en el sur del Estado.

Por lo que se refiere al desarrollo del grado en Educación Social (tabla 3), prácticamente no se produjeron demoras ni diferencias en el conjunto del Estado, disponiendo de oferta inmediatamente que se autorizaron los nuevos planes de estudio.

Las dimensiones de la oferta varían según las dimensiones de las universidades, produciéndose una clara correlación entre el tamaño de las universidades y las dimensiones de las ofertas en Educación Social (tabla 4). La media de oferta es de 87 alumnos por año académico, con variaciones entre ofertas desde 50 hasta 180 plazas. alonia Open University, but it should be borne in mind that the UIB also offers a complete distance learning course. At any event, in spite of the greater presence of distance learning in the Mediterranean area, we should not forget that the National Distance Learning University offers the course from Madrid.

The majority of the courses looked at were put in place immediately after the qualification was approved (table 2) although the speed of this varied over Spain as a whole, with slower development in the south.

In relation to the development of the degree in Social Education (table 3), there were practically no delays or differences in the country as a whole, with the course being available as soon as the new study plans were authorised.

The size of the course varies depending on the size of the universities, with there being a clear correlation between the size of the universities and the dimensions of the Social Education courses (table 4). The average was 87 students per academic year, with courses ranging in size between 50 and 180 places.

[ 66 ] MARTí XAVIER MARCH CERDÀ, CARMEN ORTE SOCIAS Y LLUÍS BALLESTER BRAGE SIPS - PEDAGOGIA SOCIAL. REVISTA INTERUNIVERSITARIA [1139-1723 (2016) 27, 45-82] TERCERA ÉPOCA 
Tabla 4. Número de plazas ofertadas de nuevo ingreso

\begin{tabular}{|l|r|}
\hline \multicolumn{2}{|c|}{ Número de plazas ofertadas de nuevo ingreso } \\
\hline N de centros & 11 \\
\hline Media & 87,0 \\
\hline Mediana & 77,5 \\
\hline Moda & 80 \\
\hline Desviación estándar & 37,28 \\
\hline Rango & 130 \\
\hline Mínimo & 50 \\
\hline Máximo & 180 \\
\hline
\end{tabular}

La oferta se encuentra perfectamente integrada en las comunidades en las que se ofertan los títulos, siendo un indicador claro el de las lenguas de la oferta (tabla 5). En las comunidades bilingües (Galicia, Cataluña, Baleares) los títulos se ofrecen en castellano y las lenguas cooficiales de cada comunidad.
Table 4. Number of places offered to new students

\begin{tabular}{|l|r|}
\hline \multicolumn{2}{|c|}{ Number of places offered to new students } \\
\hline No. Universities & 11 \\
\hline Average & 87.0 \\
\hline Median & 77.5 \\
\hline Trend & 80 \\
\hline Standard deviation & 37.28 \\
\hline Range & 130 \\
\hline Minimum & 50 \\
\hline Maximum & 180 \\
\hline
\end{tabular}

The course has been perfectly integrated into the communities where the qualification is offered, with a clear indicator being the course languages (table 5). In the bilingual communities (Galicia, Catalonia and the Balearics) the courses are offered in Spanish and the coofficial languages of each community.

Tabla 5. Lenguas utilizadas en la impartición del título según zonas del Estado

\begin{tabular}{|l|c|c|c|c|c|}
\hline \multicolumn{7}{|c|}{ Zonas del Estado } \\
\hline Lenguas utilizadas en la impartición del título & Centro y sur & Norte y oeste & Mediterráneo & Total \\
\hline \multirow{2}{*}{ Castellano } & Frecuencia & 3 & 0 & 0 & 3 \\
\cline { 2 - 6 } & $\%$ & $100,0 \%$ & $0,0 \%$ & $0,0 \%$ & $27,3 \%$ \\
\hline \multirow{2}{*}{ Castellano, lengua cooficial } & Frecuencia & 0 & 3 & 5 & 8 \\
\cline { 2 - 6 } & $\%$ & $0,0 \%$ & $100,0 \%$ & $100,0 \%$ & $72,7 \%$ \\
\hline \multirow{2}{*}{ Total } & Frecuencia & 3 & 3 & 5 & 11 \\
\cline { 2 - 6 } & $\%$ & $100,0 \%$ & $100,0 \%$ & $100,0 \%$ & $100,0 \%$ \\
\hline
\end{tabular}

Table 5. Languages used to teach the course according to areas in Spain

\begin{tabular}{|l|c|c|c|c|c|}
\hline \multicolumn{5}{|c|}{ Areas of Spain } \\
\hline Languages used to teach the course & Central and south & North and east & Mediterranean & Total \\
\hline \multirow{2}{*}{ Spanish } & Incidence & 3 & 0 & 0 & 3 \\
\cline { 2 - 6 } & $\%$ & $100.0 \%$ & $0.0 \%$ & $0.0 \%$ & $27.3 \%$ \\
\hline \multirow{2}{*}{$\begin{array}{l}\text { Spanish, co-official } \\
\text { language }\end{array}$} & Incidence & 0 & 3 & 5 & 8 \\
\hline \multirow{2}{*}{ Total } & Incidence & $0.0 \%$ & $100.0 \%$ & $100.0 \%$ & $72.7 \%$ \\
\cline { 2 - 6 } & $\%$ & $100.0 \%$ & $100.0 \%$ & $100.0 \%$ & 17 \\
\hline
\end{tabular}

Por lo que se refiere a la posibilidad de ofrecer el título de forma compartida con trabajo social, es decir, la oferta de doble grado en

The option of offering the qualification together with social work, that is to say, a double degree in Social Education and Social Work, has 
Tabla 6. Se imparte el doble grado de Educación Social y Trabajo Social según zonas del Estado

\begin{tabular}{|l|c|c|c|c|}
\hline \multicolumn{3}{|c|}{ Año de inicio } \\
\hline \multirow{2}{*}{ Se imparte el doble grado de Educación Social y Trabajo Social } & \multicolumn{2}{|c|}{2013} & \multicolumn{1}{c|}{ Total } \\
\hline \multirow{2}{*}{ No } & Frecuencia & 10 & 0 & 10 \\
\cline { 2 - 5 } & $\%$ & $100,0 \%$ & $0,0 \%$ & $0,0 \%$ \\
\hline \multirow{2}{*}{ Si } & Frecuencia & 0 & 1 & 1 \\
\hline \multirow{2}{*}{ Total } & $\%$ & $0,0 \%$ & $100,0 \%$ & $100,0 \%$ \\
\cline { 2 - 5 } & Frecuencia & 10 & 1 & 11 \\
\hline
\end{tabular}

Table 6. The double degree in Social Education and Social Work is taught according to areas in Spain

\begin{tabular}{|l|c|c|c|c|}
\hline \multirow{2}{*}{ The double degree in Social Education and Social Work is taught } & \multicolumn{2}{|c|}{ Year of commencement } \\
\hline \multirow{2}{*}{ No } & Incidence & 10 & 0 & \multicolumn{1}{c|}{ Total } \\
\cline { 2 - 5 } & $\%$ & $100.0 \%$ & $0.0 \%$ & $90.9 \%$ \\
\hline \multirow{2}{*}{ Yes } & Incidence & 0 & 1 & 1 \\
\hline \multirow{2}{*}{ Total } & $\%$ & $0.0 \%$ & $100.0 \%$ & $9.1 \%$ \\
\hline
\end{tabular}

Educación Social y Trabajo Social, solo se ha desarrollado en una de las universidades que han participado.

La experiencia de la doble titulación no parece generalizarse en el resto de universidades del Estado (tabla 7), sea por las dificultades administrativas y académicas sea por problemas de relación entre las titulaciones. En cualquier caso, parece que no se producirán cambios en breve, lo que limitará la comunicación académica entre las disciplinas de la educación social y el trabajo social. En momentos en los que las disciplinas avanzan gracias a la relación con otras disciplinas, se puede producir un freno a dicho proceso y un cierre corporativo que no beneficiará a nadie.

La Educación Social es justamente una disciplina en la que confluyen tradiciones intelectuales diversas, desde la Pedagogía hasta la Psicología, pasando por la Sociología y otras. De todas formas, las áreas de conocimiento dominantes en la configuración del título en España han sido educativas, sin lugar a dudas y sin diferencias en las diversas zonas del Estado. only been taken up by one of the universities taking part.

It seems that the double degree has not spread to the other Spanish universities (table 7) due to administrative and academic difficulties, or due to problems in linking the two qualifications. At any event, it looks like there will be no change in the short term and this will limit academic communication between the social education and social work disciplines. There are times when the disciplines move forward due to links to other disciplines, but this can produce a halt in the process and a corporate close out that is not to anyone's benefit.

Social Education is, quite rightly, a discipline where various intellectual traditions meet, from Pedagogy to Psychology via Sociology and others. However, without a doubt and with no differences between the various parts of Spain, the dominant areas of knowledge in the qualification's set up in Spain are educational.

Although this dominance of educational knowledge is clear, the involvement of differ-

[ 68 ] MARTÍ XAVIER MARCH CERDÀ, CARMEN ORTE SOCIAS Y LLUÍS BALLESTER BRAGE SIPS - PEDAGOGIA SOCIAL. REVISTA INTERUNIVERSITARIA [1139-1723 (2016) 27, 45-82] TERCERA ÉPOCA 
Tabla 7. Se tiene previsto poner en marcha la doble titulación según zonas del Estado

\begin{tabular}{|l|c|c|c|c|c|}
\hline \multicolumn{4}{|c|}{ Zonas del Estado } \\
\hline $\begin{array}{l}\text { Se tiene previsto poner en marcha la do- } \\
\text { ble titulación según zonas del Estado }\end{array}$ & Centro y sur & Norte y oeste & Mediterráneo & Total \\
\hline \multirow{2}{*}{ Si } & Frecuencia & 1 & 0 & 0 & 1 \\
\cline { 2 - 6 } & $\%$ & $100,0 \%$ & $100,0 \%$ & $60,0 \%$ & $81,8 \%$ \\
\hline \multirow{2}{*}{ No } & Frecuencia & 2 & 3 & 2 & 7 \\
\hline \multirow{2}{*}{ No sabe } & Frecuencia & $100,0 \%$ & $100,0 \%$ & $60,0 \%$ & $81,8 \%$ \\
\cline { 2 - 6 } & $\%$ & $0,0 \%$ & $0,0 \%$ & 3 & 3 \\
\hline \multirow{2}{*}{ Total } & Frecuencia & 3 & 3 & $10,0 \%$ & $18,2 \%$ \\
\hline
\end{tabular}

Table 7. It is planned to start up the double degree according to areas in Spain

\begin{tabular}{|l|c|c|c|c|c|}
\hline \multicolumn{5}{|c|}{} & \multicolumn{4}{c|}{ Areas of Spain } \\
\hline \multirow{2}{*}{ It is planned to start up the double degree } & $\begin{array}{c}\text { Central and } \\
\text { south }\end{array}$ & North and east & Mediterranean & Total \\
\hline \multirow{2}{*}{ Yes } & Incidence & 1 & 0 & 0 & 1 \\
\cline { 2 - 6 } & $\%$ & $100.0 \%$ & $100.0 \%$ & $60.0 \%$ & $81.8 \%$ \\
\hline \multirow{2}{*}{ No } & Incidence & 2 & 3 & 2 & 7 \\
\cline { 2 - 6 } & $\%$ & $100.0 \%$ & $100.0 \%$ & $60.0 \%$ & $81.8 \%$ \\
\hline \multirow{2}{*}{ Don't know } & Incidence & 0 & 0 & 3 & 3 \\
\hline \multirow{2}{*}{ Total } & $\%$ & $0.0 \%$ & $0.0 \%$ & $40.0 \%$ & $18.2 \%$ \\
\cline { 2 - 6 } & Incidence & 3 & 3 & 5 & 11 \\
\hline
\end{tabular}

Aunque ese dominio del conocimiento pedagógico sea claro, la implicación de diversos departamentos, en el desarrollo de la actividad formativa, está muy desarrollada. Como se puede ver en el cuadro 2, en cada universidad se ha producido la implicación de departamentos de las cuatro tradiciones consideradas anteriormente (Pedagogía, Psicología, Sociología), con la presencia de otras diversas áreas, en función de la configuración de los departamentos de las universidades consideradas. No es tan interesante concretar cómo se produce dicha presencia multidepartamental, siempre diversa, como comprobar que efectivamente no hay ningún título de Educación Social, entre los estudiados, que ofrezca una presencia únicamente de departamentos de Pedagogía. ent departments in developing educational activity is high. As can be seen in chart 2, each university has brought about involvement from the four traditions mentioned above (Pedagogy, Psychology and Sociology) along with the presence of other different areas, depending on how the departments in the universities considered are set up. Specifying how this multidepartmental presence, which is always diverse, occurs is not as interesting as finding out that, effectively, there is no Social Education qualification, amongst those researched, that solely offers a classroom base in the Pedagogy departments.

This observation confirms the open vocation of educational sciences departments, which are much more interdisciplinary that any others in Spanish universities. 
Tabla 8. Grandes áreas de conocimiento de los estudios de Educación Social según zonas del Estado

\begin{tabular}{|l|c|c|c|c|c|}
\hline \multicolumn{3}{|c|}{ Zonas del Estado } \\
\hline $\begin{array}{l}\text { Grandes áreas de conocimiento } \\
\text { de los estudios de Educación Social }\end{array}$ & Centro y sur & Norte y oeste & Mediterráneo & Total \\
\hline \multirow{2}{*}{ Educación } & Frecuencia & 3 & 3 & 3 & 9 \\
\cline { 2 - 5 } & $\%$ & $100,0 \%$ & $100,0 \%$ & $60,0 \%$ & $81,8 \%$ \\
\hline \multirow{2}{*}{$\begin{array}{l}\text { Educación y otras } \\
\text { (psicología) }\end{array}$} & Frecuencia & 0 & 0 & 2 & 2 \\
\hline \multirow{2}{*}{ Total } & Frecuencia & $0,0 \%$ & $0,0 \%$ & $40,0 \%$ & $18,2 \%$ \\
\cline { 2 - 5 } & $\%$ & $100,0 \%$ & $100,0 \%$ & $100,0 \%$ & $100,0 \%$ \\
\hline
\end{tabular}

Table 8. Main areas of knowledge in Social Education studies according to areas in Spain

\begin{tabular}{|l|c|c|c|c|c|}
\hline \multicolumn{5}{|c|}{} & \multicolumn{3}{c|}{ Areas of Spain } \\
\hline \multicolumn{2}{|l|}{$\begin{array}{l}\text { Main areas of knowledge in Social } \\
\text { Education studies }\end{array}$} & $\begin{array}{c}\text { Central and } \\
\text { south }\end{array}$ & North and east & Mediterranean & Total \\
\hline \multirow{2}{*}{ Education } & Incidence & 3 & 3 & 3 & 9 \\
\cline { 2 - 6 } & $\%$ & $100.0 \%$ & $100.0 \%$ & $60.0 \%$ & $81.8 \%$ \\
\hline $\begin{array}{l}\text { Education and } \\
\text { others (Psychology) }\end{array}$ & Incidence & 0 & 0 & 2 & 2 \\
\hline \multirow{2}{*}{ Total } & Incidence & 3 & 3 & $50.0 \%$ & $18.2 \%$ \\
\cline { 2 - 6 } & $\%$ & $100.0 \%$ & $100.0 \%$ & $100.0 \%$ & $100.0 \%$ \\
\hline
\end{tabular}

Dicha constatación confirma la vocación abierta de los departamentos de ciencias de la educación, mucho más interdisciplinares que cualquier otro en las universidades españolas.

Por lo que se refiere al enfoque teórico-práctico de los títulos, se puede constatar una clara implicación en todos los ámbitos socioeducativos, tanto desde los servicios sociales como educativos o culturales (cuadro 3). Sin embargo, no se quedan, los ámbitos de intervención ( $y$, por lo tanto, de prácticas, investigación etc.) en estos tres amplios sectores organizativos, ya que se observa su presencia en servicios penitenciarios y otros sectores en los que se ha configurado el Estado del Bienestar. (Amador, Esteban, Cárdenas \& Terrón, 2014).

Para dar respuesta a las necesidades formativas que requiere una diversidad profesional tan amplia, se debe garantizar la formación en un conjunto de competencias específicas también muy amplias. Realizando una categorización de todas las respuestas ofrecidas, se han cerrado las 73 respuestas diversas en las 10 más rele-
With regard to the theoretical/practical focus of the courses, a clear involvement in all socio-educational fields was observed from social and education or cultural services (chart 3). Nevertheless, they are not limited to fields of intervention (and, therefore, work experience, research, etc) in these three wide organisational sectors as there was also a presence of the penitentiary services and other services forming part of the Welfare State (Amador, Esteban, Cárdenas \& Terrón, 2014).

To respond to educational needs which require such broad professional diversity, education must be guaranteed in a group of specific skills which are also wide-ranging. Classifying all the responses received, the 73 different responses were narrowed down to the 10 most relevant (chart 4) which, necessarily, are described with a large variety of nuances.

The classification made shows how the most important specific skills were considered to be those relating to diagnosis, project and activity design, their management and the tech-

[ 70 ] MARTí XAVIER MARCH CERDÀ, CARMEN ORTE SOCIAS Y LLUÍS BALLESTER BRAGE SIPS - PEDAGOGIA SOCIAL. REVISTA INTERUNIVERSITARIA [1139-1723 (2016) 27, 45-82] TERCERA ÉPOCA 
Cuadro 2. Departamentos de los que dependen los estudios de educación social

1. Análisis e intervención psico-socioeducativa. Didáctica y organización escolar. Psicología evolutiva y de la educación. Filosofía, Ciencias políticas y Sociología.

2. Departamento de Educación. Departamento de Psicología y Sociología. Departamento de Didácticas Especiales. Departamento de Geografía e Historia.

3. Departamento de Pedagogía. Departamento de Psicología.

4. Departamento de Pedagogía. Departamento de Psicología. Departamento de Filosofía (Sociología y Antropología). Departamento de la Actividad Física y Ciencias del Deporte. Departamento de Derecho del Trabajo y Trabajo Social. Departamento de Derecho civil e Internacional Privado. Departamento de Didáctica de la Expresión Musical, Plástica y Corporal. Departamento de Historia.

5. Departamento de Pedagogía y Didácticas específicas. Departamento de Pedagogía aplicada y Psicología de la educación. Departamento de Filosofía y Trabajo social. Departamento de Psicología. Departamento de Derecho público.

6. Estudios de Psicología y Educación.

7. Métodos de Educación y Diagnóstico en Educación (MIDE), Didáctica y Organización Escolar (DOE),Teoría e Historia de la Educación (THE), Trabajo Social (TSS), Antropología, Psicología Social, Psicología Evolutiva, Música, Plástica y Artes Visuales, Educación Física.

8. Pedagogía. Psicología. Didácticas Específicas. Historia.

9. Pedagogía y Didáctica. Filosofía y Métodos de Investigación en Educación. Psicología. Psicología Evolutiva y de la Educación. Sociología y Ciencia Política de la Administración (departamento no adscrito).

10. Teoría de la educación, Historia de la educación y Pedagogía Social. Didáctica y Organización Escolar. Métodos de Investigación y Diagnóstico en Educación. Psicología Evolutiva y de la Educación. Psicología Social, Básica y Metodología.

11. Teoría e Historia. MIDE. DOE. Psicología evolutiva y de la educación. Sociología VI. Expresión musical y corporal. Expresión plástica.

vantes (cuadro 4), necesariamente se han descrito con una gran variedad de matices.

La categorización realizada, muestra cómo las competencias específicas más importantes consideradas son las relativas al diagnóstico, el di-
Chart 2. Departments that social education studies come under

1. Psycho-social educational analysis and intervention. Teaching and organisation in schools. Evolutionary and educational psychology. Philosophy, Political sciences and Sociology.

2. Department of Education. Department of Psychology and Sociology. Department of Special Learning. Department of Geography and History

3. Department of Pedagogy. Department of Psychology

4. Department of Pedagogy. Department of Psychology. Department of Philosophy (Sociology and Anthropology). Department of Physical Activity and Sports Sciences. Department of Employment and Social Work Law. Department of Civil and International Private Law. Department of Teaching Musical, Artistic and Bodily Expression. Department of History.

5. Department of Pedagogy and Specific Teaching techniques. Department of Applied Pedagogy and Education Psychology. Department of Philosophy and Social Work. Department of Psychology. Department of Public Law

6. Psychology and Education Studies

7. Educational methods and diagnostics ("MIDE"), Teaching and Guidance in Schools ("DOE"), Education Theory and History ("THE"), Social Work ("TSS"), Anthropology, Social Psychology, Developmental Psychology, Music and Visual and Plastic Arts, Physical Education

8. Pedagogy, Psychology, Specific Teaching techniques. History

9. Pedagogy and Teaching. Education Philosophy and Research Methods. Psychology. Developmental Psychology in Education. Sociology and Political Sciences in Public Authorities (unassigned department)

10. Theory of Education. History of education and Social Pedagogy. Teaching and Organisation in Schools. Research and Diagnostics methods in Education. Developmental Psychology and Education. Basic Social Psychology and Methodology

11. Theory and History. MIDE. DOE. Developmental Psychology and education. Sociology VI. Musical expression and body language. Visual expression.

niques involved. These four skills are those providing the most responses from the heads of courses. As can be seen, they were presented with the need to select the 10 most relevant specific skills, so that it can be concluded that 
seño de proyectos y actividades, la gestión de las mismas y las técnicas implicadas. Estas cuatro competencias son las que ofrecen más respuestas entre los responsables de las titulaciones. Como se puede ver, se les planteó la necesidad de seleccionar las 10 competencias específicas más relevantes, por lo que se puede concluir que dichas competencias se orientan a la intervención socioeducativa, aunque sin olvidar los fundamentos en el diagnóstico.

Cuadro 3. Ámbitos de intervención de la titulación en educación social

Adultos y mayores: educación permanente, a lo largo de
la vida, orientación ocupacional
Animación sociocultural/ocio y tiempo libre, gestión so-
ciocultural
Dependencia y acompañamiento a la autonomía
Desadaptación social y colectivos vulnerables: menores
en desprotección y conflicto, familias en riesgo, minorías,
discapacidad, adicciones, servicios sociales en general
Desarrollo comunitario
Discapacidades
Educación ambiental
Educación familiar
Educación para el desarrollo
Educación para la mediación, la inclusión social y la di-
versidad
Educación permanente:
Exclusión social y atención educativa a colectivos desfa-
vorecidos
Globalización y acción socioeducativa en la diversidad
Grupos en conflicto social
Infancia y adolescencia. Acogida y adopción.
Infancia y juventud
Infancia, familias y mediación educativa
Inserción social
Instituciones para el cumplimiento de medidas judiciales
Integración social
Interculturalidad
Marginación
Mayores/educacioción sociolaboral
Oeros ero igualón yociosanitarios

such skills are directed at socio-educational intervention, but without forgetting a grounding in diagnostics.

With respect to the professors' education, it could never be said that we are talking about under-qualification, instead it is quite to the contrary (Table 9). The presence of highly qualified professors is an indicator of the significant value that the course has acquired over the last twenty years. Currently the percent-

Chart 3. Areas of intervention for social education qualification holders

\begin{tabular}{l} 
Adults and the elderly: permanent, life-long learning, oc- \\
cupational training \\
Socio-cultural/leisure and spare time support, socio-cul- \\
tural management \\
\hline Dependence and helping to independence \\
\hline Social misfit and vulnerable groups: unprotected and in \\
conflict minors, families at risk, minorities, disability, ad- \\
dictions, social services in general \\
\hline Community developmentDisabilities \\
\hline Environmental education \\
\hline Family education \\
\hline Education for development \\
\hline Education for mediation, social inclusion and diversity \\
\hline Permanent learning \\
\hline Social Exclusion and educational care of disadvantaged \\
groups \\
\hline Globalisation and socio-educational action for diversity \\
\hline Groups in social conflict \\
\hline Childhood and adolescence. Fostering and adoption. \\
\hline Childhood and youth \\
\hline Childhood, families and educational mediation \\
\hline Social Insertion \\
\hline Interculturality \\
\hline Marginalisation \\
\hline The elderly/permanent learning, Guidance and TIC \\
\hline Social and occupational mediation \\
\hline Women. Gender and equality \\
\hline Leisure time and socio-cultural support \\
\hline Elderly people \\
\hline Prisons \\
\hline Socialth and Welfare Services \\
\hline
\end{tabular}

[ 72 ] MARTí XAVIER MARCH CERDÀ, CARMEN ORTE SOCIAS Y LLUÍS BALLESTER BRAGE SIPS - PEDAGOGIA SOCIAL. REVISTA INTERUNIVERSITARIA [1139-1723 (2016) 27, 45-82] TERCERA ÉPOCA 
Cuadro 4. Competencias específicas de la titulación (las 11 más relevantes)

\begin{tabular}{|c|c|}
\hline ו POLÍTICAS & $\begin{array}{l}\text { Conocer las políticas de bienestar social } \\
\text { y la legislación que sustentan los proce- } \\
\text { sos de intervención socioeducativa. }\end{array}$ \\
\hline 2 DIAGNÓSTICO & $\begin{array}{l}\text { Comprensión de los procesos, institu- } \\
\text { ciones e ideas que se han dado históri- } \\
\text { camente y que han configurado los mo- } \\
\text { delos actuales de intervención } \\
\text { socioeducativa. }\end{array}$ \\
\hline 3 DIAGNÓSTICO & $\begin{array}{l}\text { Analizar y diagnosticar la realidad com- } \\
\text { pleja que fundamenta el desarrollo de los } \\
\text { procesos socioeducativos. }\end{array}$ \\
\hline 4 DIAGNÓSTICO & $\begin{array}{l}\text { Estar capacitado/a para el diagnostico y } \\
\text { la mediación en la prevención y resolu- } \\
\text { ción de conflictos en condiciones de de- } \\
\text { sigualdad y crisis en comunidades socio- } \\
\text { educativas. }\end{array}$ \\
\hline 5 DISEÑO & $\begin{array}{l}\text { Diseñar, organizar, gestionar y evaluar } \\
\text { programas, proyectos y servicios socioe- } \\
\text { ducativos en los ámbitos de la educación } \\
\text { familiar y el desarrollo comunitario, la in- } \\
\text { tegración social, la animación y la gestión } \\
\text { cultural, de la infancia y juventud y de la } \\
\text { gente mayor. }\end{array}$ \\
\hline 6 DISEÑO & $\begin{array}{l}\text { Diseñar, aplicar y evaluar programas y es- } \\
\text { trategias de intervención socioeducativa } \\
\text { en el ámbito del desarrollo comunitario y } \\
\text { cooperación al desarrollo. }\end{array}$ \\
\hline 7 GESTIÓN & $\begin{array}{l}\text { Desarrollar programas y proyectos en el } \\
\text { contexto familiar y escolar, así como en } \\
\text { educación especializada (menores, ne- } \\
\text { cesidades educativas especiales, cen- } \\
\text { tros de salud, conductas aditivas, institu- } \\
\text { ciones penitenciarias, y personas y } \\
\text { colectivos en riesgo de exclusión...). }\end{array}$ \\
\hline 8 GESTIÓN & $\begin{array}{l}\text { Gestionar estructuras, procesos y progra- } \\
\text { mas de participación y acción comunitaria. }\end{array}$ \\
\hline 9 TÉCNICAS & $\begin{array}{l}\text { Utilizar técnicas concretas de interven- } \\
\text { ción socioeducativa y comunitaria (diná- } \\
\text { mica de grupos, motivación, negociación, } \\
\text { asertividad, etc.), los procedimientos y } \\
\text { técnicas sociopedagógicas para la inter- } \\
\text { vención, la mediación y el análisis de la } \\
\text { realidad personal, familiar y social. }\end{array}$ \\
\hline 10 TÉCNICAS & $\begin{array}{l}\text { Diseño y uso de los medios, recursos y } \\
\text { estrategias para la intervención socioe- } \\
\text { ducativa e incorporarlos en los diferen- } \\
\text { tes ámbitos de acción socioeducativa. }\end{array}$ \\
\hline 1 EVALUAR & $\begin{array}{l}\text { Evaluar procesos, medios, recursos y resul- } \\
\text { tados de la intervención socioeducativa. }\end{array}$ \\
\hline
\end{tabular}

Chart 4. Specific skills included in the degree (the 11 most important)

\begin{tabular}{|c|c|}
\hline 1. POLICIES & $\begin{array}{l}\text { Learn about social welfare policies and } \\
\text { the legislation supporting socio-educa- } \\
\text { tional intervention processes. }\end{array}$ \\
\hline 2. DIAGNOSTICS & $\begin{array}{l}\text { Understanding the historical processes, } \\
\text { institutions and ideas which have sha- } \\
\text { ped current socio-educational interven- } \\
\text { tion models. }\end{array}$ \\
\hline 3. DIAGNOSTICS & $\begin{array}{l}\text { Analyse and diagnose the complex rea- } \\
\text { lity which is the basis for development } \\
\text { of socio-educational processes. }\end{array}$ \\
\hline 4. DIAGNOSTICS & $\begin{array}{l}\text { Be trained in diagnostics and mediation } \\
\text { in conflict prevention and resolution in } \\
\text { situations of inequality and crisis in so- } \\
\text { cio-educational communities. }\end{array}$ \\
\hline 5. DESIGN & $\begin{array}{l}\text { Design, organise, manage and assess } \\
\text { socio-educational programmes, pro- } \\
\text { jects and services within the sphere of } \\
\text { family education and community deve- } \\
\text { lopment, social integration, promoting } \\
\text { and managing cultural initiatives, chil- } \\
\text { dren, youth and the elderly. }\end{array}$ \\
\hline 6. DESIGN & $\begin{array}{l}\text { Design, apply and assess programmes } \\
\text { and strategies for socio-educational in- } \\
\text { tervention in the field of community de- } \\
\text { velopment and cooperation in develop- } \\
\text { ment. }\end{array}$ \\
\hline 7. MANAGEMENT & $\begin{array}{l}\text { Develop programmes and projects in a } \\
\text { family and academic context and also in } \\
\text { specialist education (minors, special edu- } \\
\text { cational needs, health centres, addictive } \\
\text { behaviour, penal institutions and people } \\
\text { and groups at risk of exclusion, etc. }\end{array}$ \\
\hline 8. MANAGEMENT & $\begin{array}{l}\text { Manage structures, processes and pro- } \\
\text { grammes for community participation } \\
\text { and action. }\end{array}$ \\
\hline 9. TECHNIQUES & $\begin{array}{l}\text { Use specific techniques for socio-edu- } \\
\text { cational and community intervention } \\
\text { (group dynamics, motivation, negotia- } \\
\text { tion, assertiveness, etc), socio-pedago- } \\
\text { gic procedures and techniques for in- } \\
\text { tervention, mediation and analysis of } \\
\text { personal, family and social realities. }\end{array}$ \\
\hline 10. TECHNIQUES & $\begin{array}{l}\text { Design and use of media, resources and } \\
\text { strategies for socio-educational interven- } \\
\text { tion and incorporating them into the va- } \\
\text { rious fields of socio-educational action. }\end{array}$ \\
\hline 11. ASSESSMENT & $\begin{array}{l}\text { Assess socio-educational intervention } \\
\text { processes, media, resources and results. }\end{array}$ \\
\hline
\end{tabular}


Tabla 9. Tipo de profesorado según zonas del Estado

\begin{tabular}{|c|c|c|c|c|c|}
\hline \multicolumn{6}{|c|}{ Zonas del Estado } \\
\hline Profesorado & & Centro y sur & Norte y oeste & Mediterráneo & Total \\
\hline \multirow{2}{*}{ Catedráticos } & Frecuencia & 5 & 3 & 5 & 13 \\
\hline & $\%$ & $15,6 \%$ & $10,3 \%$ & $13,2 \%$ & $13,1 \%$ \\
\hline \multirow{2}{*}{$\begin{array}{l}\text { Titulares } \\
\text { Universidad }\end{array}$} & Frecuencia & 5 & 7 & 9 & 27 \\
\hline & $\%$ & $15,6 \%$ & $24,1 \%$ & $23,7 \%$ & $21,2 \%$ \\
\hline \multirow{2}{*}{$\begin{array}{l}\text { Catedráticos de } \\
\text { Escuela Univer. }\end{array}$} & Frecuencia & 2 & O & 0 & 2 \\
\hline & $\%$ & $6,3 \%$ & O,०\% & $0,0 \%$ & $2,0 \%$ \\
\hline \multirow{2}{*}{$\begin{array}{l}\text { Titulares de } \\
\text { Escuela Univer. }\end{array}$} & Frecuencia & 2 & 2 & 2 & 6 \\
\hline & $\%$ & $6,3 \%$ & $6,9 \%$ & $5,3 \%$ & $6,1 \%$ \\
\hline \multirow{2}{*}{ Ayudantes } & Frecuencia & 2 & 2 & 3 & 7 \\
\hline & $\%$ & $6,3 \%$ & $6,9 \%$ & $7,9 \%$ & $7,1 \%$ \\
\hline \multirow{2}{*}{$\begin{array}{l}\text { Ayudante } \\
\text { Doctor }\end{array}$} & Frecuencia & 3 & 4 & 3 & 10 \\
\hline & $\%$ & $9,4 \%$ & $13,8 \%$ & $7,9 \%$ & $10,1 \%$ \\
\hline \multirow{2}{*}{ Colaboradores } & Frecuencia & 1 & 1 & 2 & 4 \\
\hline & $\%$ & $3,1 \%$ & $3,4 \%$ & $5,3 \%$ & $4,0 \%$ \\
\hline \multirow{2}{*}{$\begin{array}{l}\text { Contratado } \\
\text { Doctor }\end{array}$} & Frecuencia & 4 & 5 & 6 & 15 \\
\hline & $\%$ & $12,5 \%$ & $17,2 \%$ & $15,8 \%$ & $15,2 \%$ \\
\hline \multirow{2}{*}{ Asociados } & Frecuencia & 8 & 5 & 8 & 21 \\
\hline & $\%$ & $25,0 \%$ & $17,2 \%$ & $21,1 \%$ & $21,2 \%$ \\
\hline \multirow{2}{*}{ Total } & Frecuencia & 32 & 29 & 38 & 99 \\
\hline & $\%$ & $100, \bigcirc \%$ & $100,0 \%$ & $100, \bigcirc \%$ & $100,0 \%$ \\
\hline
\end{tabular}

Table 9. Type of professors according to areas in Spain

\begin{tabular}{|c|c|c|c|c|c|}
\hline \multicolumn{6}{|c|}{ Areas of Spain } \\
\hline Professors & & Central and South & North and east & Mediterranean & Total \\
\hline \multirow{2}{*}{ Lecturer } & Incidence & 5 & 3 & 5 & 13 \\
\hline & $\%$ & $15.6 \%$ & $10.3 \%$ & $13.2 \%$ & $13.1 \%$ \\
\hline \multirow{2}{*}{$\begin{array}{l}\text { University } \\
\text { Graduates }\end{array}$} & Incidence & 5 & 7 & 9 & 21 \\
\hline & $\%$ & $15.6 \%$ & $24.1 \%$ & $23.7 \%$ & $21.2 \%$ \\
\hline \multirow{2}{*}{$\begin{array}{l}\text { University School } \\
\text { professors }\end{array}$} & Incidence & 2 & 0 & 0 & 2 \\
\hline & $\%$ & $6.3 \%$ & $0.0 \%$ & $0.0 \%$ & $2.0 \%$ \\
\hline \multirow{2}{*}{$\begin{array}{l}\text { University School } \\
\text { Graduates }\end{array}$} & Incidence & 2 & 2 & 2 & 6 \\
\hline & $\%$ & $6.3 \%$ & $6.9 \%$ & $5.3 \%$ & $6.1 \%$ \\
\hline \multirow{2}{*}{$\begin{array}{l}\text { Assistant } \\
\text { lecturers }\end{array}$} & Incidence & 2 & 2 & 3 & 7 \\
\hline & $\%$ & $6.3 \%$ & $6.9 \%$ & $7.9 \%$ & $7.1 \%$ \\
\hline \multirow{2}{*}{$\begin{array}{l}\text { Assistant PhD } \\
\text { lecturers }\end{array}$} & Incidence & 3 & 4 & 3 & 10 \\
\hline & $\%$ & $9.4 \%$ & $13.8 \%$ & $7.9 \%$ & $10.1 \%$ \\
\hline \multirow{2}{*}{ Guest lecturers } & Incidence & 1 & 1 & 2 & 4 \\
\hline & $\%$ & $3.1 \%$ & $3.4 \%$ & $5.3 \%$ & $4.0 \%$ \\
\hline \multirow{2}{*}{$\begin{array}{l}\text { Temporary PhD } \\
\text { lecturers }\end{array}$} & Incidence & 4 & 5 & 6 & 15 \\
\hline & $\%$ & $12.5 \%$ & $17.2 \%$ & $15.8 \%$ & $15.2 \%$ \\
\hline \multirow{2}{*}{$\begin{array}{l}\text { Associate } \\
\text { lecturers }\end{array}$} & Incidence & 8 & 5 & 8 & 21 \\
\hline & $\%$ & $25.0 \%$ & $17.2 \%$ & $27.1 \%$ & $21.2 \%$ \\
\hline \multirow{2}{*}{ Total } & Incidence & 32 & 29 & 38 & 99 \\
\hline & $\%$ & $100.0 \%$ & $100.0 \%$ & $100.0 \%$ & $100.0 \%$ \\
\hline
\end{tabular}

[ 74 ] MARTí XAVIER MARCH CERDÀ, CARMEN ORTE SOCIAS Y LLUÍS BALLESTER BRAGE SIPS - PEDAGOGIA SOCIAL. REVISTA INTERUNIVERSITARIA [1139-1723 (2016) 27, 45-82] TERCERA ÉPOCA 
Por lo que se refiere a la dotación del profesorado, no se puede decir que se trate de títulos de menor consideración, sino más bien al contrario (Tabla 9). La presencia de profesorado con altos niveles formativos, es un indicador del valor relevante que ha llegado a adquirir la titulación en los últimos veinte años. Actualmente, el porcentaje de profesorado permanente con largos procesos formativos (desde catedráticos hasta TEU) es muy importante, Ilegando a representar el $42,4 \%$ del conjunto del profesorado implicado.

En cualquier caso, con el deterioro que se ha producido en la universidad española en los últimos cuatro años, tal vez se empiece a observar pronto una reducción del profesorado permanente, aunque no tenga por qué reducirse el nivel formativo del mismo.

Como se puede observar en la tabla 10, el nivel formativo actual es muy elevado, con una presencia muy alta de profesorado doctor, siendo en las tres zonas del Estado superior al $65 \%$ del conjunto del profesorado (tabla 10). Es age of permanent professors with extensive education (from lecturers to university professors) is highly significant, as it includes $42.4 \%$ of the group of professors involved.

At any event, with the impairment that has occurred in Spanish universities in the last four years it could be that we will soon see a reduction in permanent professors, although this does not necessarily mean a reduction in their level of education.

As can be seen in table 10, the current level of qualifications is very high, with a very large number of professors holdings doctorates and accounting for over $65 \%$ of all the professors in the three Spanish zones (table 10). That is to say, a degree of impairment may occur which puts professors' jobs in jeopardy but not their level of qualification. At any event, a result of such an impairment would be a reduction in the capacity for research by the course's teaching teams, which is a significant matter for a qualification that is bound to a discipline in the process of development.

Tabla 10. Profesorado doctor según zonas del Estado

\begin{tabular}{|l|c|c|c|}
\hline \multicolumn{3}{|c|}{ Zonas del Estado } \\
\hline Profesorado doctor & Centro y sur & Norte y oeste & Mediterráneo \\
\hline N de centros & 11 & 11 & 11 \\
\hline Media de doctores por centro & 15,0 & 26,6 & 15,7 \\
\hline Mediana & 15,0 & 24,0 & 17,0 \\
\hline Desviación estándar & 5,66 & 9,29 & 2,50 \\
\hline Mínimo & 11 & 37 & 12 \\
\hline Máximo & 19 & $72,4 \%$ & 17 \\
\hline \% del profesorado & $65,6 \%$ & $65,8 \%$ \\
\hline
\end{tabular}

Table 10. PhD professors according to areas in Spain

\begin{tabular}{|l|c|c|c|}
\hline \multicolumn{3}{|c|}{ Areas of Spain } \\
\hline PhD professors & Central and south & North and east & Mediterranean \\
\hline No. universities & 11 & 17 & 17 \\
\hline Average PhD's per university & 15,0 & 26,6 & 15,7 \\
\hline Mean & 15,0 & 24,0 & 17,0 \\
\hline Standard deviation & 5,66 & 9,29 & 2,50 \\
\hline Minimum & 11 & 19 & 12 \\
\hline Maximum & 19 & 37 & 17 \\
\hline \% of professors & $65,6 \%$ & $72,4 \%$ & $65,8 \%$ \\
\hline
\end{tabular}


Cuadro 5. Metodologías docentes más utilizadas

\begin{tabular}{|c|c|}
\hline 1 EXPOSICIÓN & Exposición teórica y clase magistral \\
\hline \multirow{4}{*}{2 DEBATE } & Comentarios de texto, de material audiovisual \\
\hline & Debates \\
\hline & Discusión dirigida \\
\hline & Seminarios \\
\hline \multirow{2}{*}{3 ANÁLISIS DE CASOS } & Aprendizaje basado en problemas; aprendizaje orientado a proyectos \\
\hline & Estudio de casos \\
\hline 4 PRESENTACIONES & Presentación trabajos alumnado \\
\hline \multirow{6}{*}{5 EJERCICIOS Y PROYECTOS } & Prácticas en el aula \\
\hline & Prácticas mediante las TIC \\
\hline & Realización de proyectos \\
\hline & Resolución de problemas y ejercicios \\
\hline & Trabajo en pequeño grupo \\
\hline & Trabajo presencial \\
\hline 6 TALLERES & Talleres prácticos \\
\hline \multirow{3}{*}{7 TUTORÍAS } & Actividades grupales tutorizadas \\
\hline & Aprendizaje colaborativo / Trabajo tutelado \\
\hline & Tutorías individuales y en grupo \\
\hline \multirow{2}{*}{8 TRABAJO AUTÓNOMO } & Aprendizaje cooperativo; contrato de aprendizaje \\
\hline & Trabajo autónomo \\
\hline \multirow{2}{*}{ 9 SALIDAS } & Salidas de estudio \\
\hline & Visitas a instituciones y experiencias \\
\hline
\end{tabular}

Chart 5. Most used teaching methodologies

\begin{tabular}{|c|c|}
\hline 1 LECTURE & Theory lecture and master class \\
\hline \multirow{4}{*}{2 DEBATE } & Commentaries on text and audiovisual material \\
\hline & Debates \\
\hline & Directed discussion \\
\hline & Seminars \\
\hline \multirow{2}{*}{3 CASE ANALYSIS } & Problem-based learning, learning directed at projects \\
\hline & Case study \\
\hline 4 PRESENTATIONS & Presentation of students' work \\
\hline \multirow{6}{*}{5 EXERCISES and PROJECTS } & Classroom practicals \\
\hline & ITC Practicals \\
\hline & Project development \\
\hline & Problem and exercise solving \\
\hline & Working in small groups \\
\hline & Working in the classroom \\
\hline 6 WORKSHOPS & Practical workshops \\
\hline \multirow{3}{*}{7 TUTORIALS } & Tutored group activities \\
\hline & Collaborative learning/Tutored work \\
\hline & Individual and group tutorials \\
\hline \multirow{2}{*}{8 INDEPENDENT STUDY } & Cooperative learning, learning contract \\
\hline & Independent study \\
\hline \multirow{2}{*}{9 OUTINGS } & Study outings \\
\hline & Visits to institutions and experiences \\
\hline
\end{tabular}

[ 76 ] MARTí XAVIER MARCH CERDÀ, CARMEN ORTE SOCIAS Y LLUÍS BALLESTER BRAGE SIPS - PEDAGOGIA SOCIAL. REVISTA INTERUNIVERSITARIA [1139-1723 (2016) 27, 45-82] TERCERA ÉPOCA 
Cuadro 6. Sistemas de evaluación más utilizados

\begin{tabular}{|c|c|}
\hline \multirow{9}{*}{ I EXÁMENES } & Examen, combinando tipos \\
\hline & Examen de desarrollo \\
\hline & Examen tipo test \\
\hline & Pruebas de desarrollo \\
\hline & Pruebas de ejecución de tareas reales o simuladas \\
\hline & Pruebas de evaluación continua \\
\hline & Pruebas de respuesta corta \\
\hline & Pruebas de sintesis \\
\hline & Pruebas de tipo test \\
\hline \multirow{8}{*}{2 ACTIVIDADES, EJERCICIOS } & Actividades prácticas de aula \\
\hline & Comentarios de textos \\
\hline & Estudio de casos \\
\hline & Exposiciones por parte de los estudiantes \\
\hline & Prácticas de aula individuales y grupales \\
\hline & Presentación oral \\
\hline & Trabajo tutelado / Aprendizaje colaborativo \\
\hline & Trabajos de aula \\
\hline \multirow{4}{*}{3 ACTIVIDADES EN GRUPO } & Exposiciones grupales \\
\hline & Trabajo grupal \\
\hline & Trabajos de grupo: exposiciones \\
\hline & Trabajos escritos grupales \\
\hline \multirow{3}{*}{4 PORTAFOLIOS } & Carpetas de aprendizaje (Portafolios) \\
\hline & Portafolio individual \\
\hline & Portafolios grupales \\
\hline \multirow{2}{*}{5 TRABAJOS DE CURSO } & Informes y memorias \\
\hline & Trabajos monográficos o de curso en grupo \\
\hline
\end{tabular}

Chart 6. Most common assessment systems

\begin{tabular}{|c|c|}
\hline \multirow{9}{*}{1 EXAMS } & Combined-type exam \\
\hline & Development exam \\
\hline & Test-type exam \\
\hline & Development tests \\
\hline & Tests on execution of real or simulated tasks \\
\hline & Continuous assessment tests \\
\hline & Short answer tests \\
\hline & Synthesis tests \\
\hline & Tests \\
\hline \multirow{8}{*}{2 ACTIVITIES, EXERCISES } & Classroom practical activities \\
\hline & Commentaries on texts \\
\hline & Case studies \\
\hline & Presentations by students \\
\hline & Individual and group classroom practicals \\
\hline & Oral presentation \\
\hline & Tutored work/Collaborative learning \\
\hline & Classroom work \\
\hline \multirow{4}{*}{3 GROUP ACTIVITIES } & Group presentations \\
\hline & Group work \\
\hline & Group work: presentations \\
\hline & Group written work \\
\hline \multirow{3}{*}{4 PORTFOLIOS } & Learning files (Portfolios) \\
\hline & Individual portfolios \\
\hline & Group portfolios \\
\hline \multirow{2}{*}{5 COURSE WORK } & Reports and memoranda \\
\hline & Group case or course work \\
\hline
\end{tabular}


decir, se puede producir un nivel de deterioro, de precarización laboral del profesorado, pero no de su nivel formativo. En cualquier caso, una consecuencia de dicho deterioro será la reducción de la capacidad de investigación de los equipos docentes de la titulación, tema muy relevante para una titulación vinculada a una disciplina en proceso de desarrollo.

Por lo que se refiere a la calidad de la docencia impartida, uno de los indicadores es la diversificación y actualización de las metodologías docentes. Si las exposiciones magistrales eran absolutamente dominantes hace veinte años, al inicio de la implantación de los títulos de educación social, actualmente se puede observar una gran diversidad de metodología (cuadro 5), incluyendo una gran variedad de modalidades que se han podido categorizar en las nueve dominantes que se presentan en el cuadro 5.

Finalmente, se puede completar el análisis de la mejora de la docencia prestando atención a los sistemas de evaluación (cuadro 6). De la misma manera que se ha producido una gran diversificación de las metodologías, se observa una gran diversidad de sistemas de evaluación, categorizadas en cinco grandes grupos que muestran la pérdida de centralidad de los exámenes convencionales, actualmente acompañados en todo el Estado de ejercicios de diversos tipos, actividades grupales y otras modalidades.

\section{Discusión: los peligros reales para la Pedagogía Social}

Hemos realizado una aproximación analítica a la Pedagogía Social (PS) en España teniendo en cuenta sus puntos fuertes y débiles. Entre los puntos fuertes, se ha profundizado en el impacto de la implantación de los estudios de Educación Social (ES) hace dos décadas, tanto en el desarrollo de la PS, como en la reconstrucción de las Ciencias de la Educación. También se ha destacado, por un lado, la relación entre el conjunto de elementos que integran la titulación de ES (el propio currículo formativo o la formación multidisciplinar) y, por otro lado, la
When it comes to the quality of the teaching given, one of the indicators is the diversification and updating of teaching methodologies. If lectures were absolutely dominant twenty years ago, when social education first appeared as a qualification, currently a wide diversity of methodology can be seen (chart 5) including a large variety of modules which it has been possible to classify into the nine dominant ones shown in chart 5 .

Finally, the analysis of improvement in teaching can be completed by paying attention to the assessment systems (chart 6). In the same way as a wide diversification of methodologies occurred, a wide diversity of assessment systems can be seen, classified into five large groups which demonstrate the loss of the central focus on conventional exams, which are currently accompanied in Spain by various types of exercises, group activities and other modules.

\section{Discussion: The real risks for Social Pedagogy}

We took an analytical approach to Social Pedagogy in Spain, taking into account its strong and weak points. Among the strong points, the impact of putting Social Education studies in place two decades ago has deepened, both in the development of Social Pedagogy and the reconstruction of Educational Sciences. On the one hand, the relationship between the group of elements making up the Social Education qualification is noteworthy (the course curriculum itself or the multi-disciplinary education) and, on the other, the relationship with 
relación con las instituciones sociales durante el proceso formativo de los egresados.

Ello ha generado una percepción social positiva y de cercanía a los problemas sociales reales, respecto del profesional de la educación social. Tal como recogen los datos aportados aquí, la educación social ha tenido un desarrollo muy importante en la Universidad en términos de puesta en marcha de titulaciones, formación del profesorado universitario, oferta de asignaturas y titulaciones de especialización en posgrado en las dos últimas décadas. Es pues un momento pleno de oportunidades para abordar algunas de las debilidades de la PS. Aunque desde el punto de vista de la titulación, ampliar la oferta no presencial, o generalizar la oferta de un doble recorrido educación social/trabajo social, es una oportunidad, que sin duda aportará diversos beneficios tanto a la titulación, como a los egresados y a la creación de grupos de investigación multidisciplinares en el ámbito educativo-social.

Pensamos que la debilidad más importante y reto a la vez de la PS, es la respuesta acreditada a los problemas de su competencia. Ello significa, como hemos comentado, abordar la evaluación de las acciones que se llevan a cabo desde una perspectiva científica, y con capacidad de generalización de los resultados de las acciones que se llevan a cabo. Significa también potenciar la investigación de los problemas sociales utilizando como referente la evidencia científica como fundamento de la acción socioeducativa. Significa, asimismo, ampliar los mecanismos de conocimiento y generalización de los resultados de las acciones, a través del mismo proceso formativo de los egresados, la ampliación de grupos de investigación, la internacionalización del conocimiento. En definitiva, profundizar en la acción socioeducativa basada en las evidencias, tomando como contexto investigador los estudios de Educación Social. Un reto que pensamos es viable y que sin duda ampliará de forma exponencial, el impacto de la PS, de los estudios de ES, y la credibilidad del profesional de la educación social. social institutions during the graduate training process.

This has created a positive social perception and one of proximity to real social problems with respect to the social education professional. As shown by the data provided here, social education has undergone significant development at the University in terms of putting qualifications in place, the level of education of the university professors and the offer of specialist post graduate qualifications and subjects over the last twenty years. It is, therefore, a time filled with opportunities to address some of Social Pedagogy's weaknesses. From the point of view of the qualification, broadening the offer of distance learning, or generalising the offer of a dual social education/social work course are opportunities which, without doubt, would provide many benefits to the qualification as well as to graduates and the creation of multi-disciplinary research groups within the socio-educational field.

We believe that the most significant weakness, and at the same time challenge, for Social Pedagogy is accredited response to the problems in its field. This means, as we have mentioned, addressing assessment of the actions carried out from a scientific perspective and with a capacity to generalise the results of the actions carried out. It also means boosting research into social problems using scientific evidence as a reference base for socio-educational action. Furthermore, it means broadening knowledge mechanisms and spreading the results of actions via the actual training of the graduates, extending research groups and internationalising knowledge. Ultimately the aim is to deepen evidence-based socio-educational action taking Social Education studies as the investigative context. This is a goal which we think is feasible and which, without doubt, would widen the impact of Social Pedagogy, Social Education studies and the credibility of professional social educators exponentially. 


\section{Referencias / References}

Amador, L.V., Esteban, M., Cárdenas, R., \& Terrón, M.T. (2014). Ámbitos de profesionalización del educador/a social: perspectivas y complejidad. Revista de humanidades, 21, 1-15.

Ballester, L., Nadal, A., \& Amer, J. (2014). Métodos y técnicas de investigación educativa. Palma: UIB edicions.

Barriga, S. (1990). Intervención social y evaluación de programas: implicaciones sociopolíticas. Revista de Psicología Social, 5(2-3), 267-280.

Baumrind, D. (1971). Current patterns of parental authority. Developmental Psychology Monographs (41), 1-103.

Caride, J. A., Gradaílle, R., \& Caballo, M. B. (2015). De la pedagogía social como educación, a la educación social como Pedagogía. Perfiles educativos, 37(148), 04-11.

Denzin, N.K., \& Lincoln,Y.S. (coords.). (2013). Las estrategias de investigación cualitativa. Barcelona: Editorial Gedisa.

Duţă, N., Forés, A., \& Novella, A. M. (2015). Challenges of social education of Catalonia to Romania. Procedia-Social and Behavioral Sciences, 180, 1086-1093.

Forés, A., \& Novella, A. (coords.) (2013). 7 retos para la educación social. Reinventarse como profesional de lo social, nuevos desafíos para la empleabilidad. Barcelona: Editorial Gedisa.

Janer, A., \& Úcar, X. (2014). Pedagogía social: una aproximación a las dimensiones e indicadores que la configuran. In P. Delgado, S. Barros, C. Serrão, S. Veiga, T. Martins, A.J. Guedes, F. Diogo \& M.J. Araújo (coords.). Pedagogia / Educação Social - Teorias \& Práticas. Espaços de investigação, formação e ação, pp.515-522. Porto: Escola Superior de Educação do Politécnico do Porto.

Kochanska, G., Murray, K., \& Coy, K. (1997). Inhibitory control as a contributor to conscience in childhood: from toddler to early school age. Child Development (68), 173-186.

Kumpfer, K. L., Demarsh, J. P., \& Child, W. (1989). Strengthening Families Program: Children's Skills Training Curriculum Manual (Prevention Services to Children of Substance-abusing Parents). Utah: Social Research Institute, Graduate School of Social Work, University of Utah.

Kumpfer, K.L. (1998). Selective prevention interventions: the strengthening families program. In R.S. Ashery, E.B. Robertson \& K.L. Kumpfer (Eds.). Drug Abuse Prevention Through Family Interventions (NIDA Research Monograph No. 177. NIH Publication No. 99-4135) Washington DC: U.S. Government Priting Office.

Kumpfer, K.L., \& Demarsh, J. (1985). Genetic and family environmental influences on children of drug abusers. Journal of Children in Contemporary Society, 3/4 (Far1).

Lila, M., Musitu, G., \& Buelga, S. (2001). Adolescentes colombianos y españoles: diferencias, similitudes y relaciones entre la socialización familiar, la autoestima y los valores. Revista Latinoamericana de Psicología (32), 301-319.

Lila, M. \& Gracia, E. (2005). Determinantes de la aceptación-rechazo parental. Psicothema 47(17), 107-111.

March, M.X. \& Orte, C. (coords.) (2014). La pedagogía social y la escuela. Barcelona: Octaedro.

Musitu, G. \& García, F. (2004). Consecuencias de la socialización familiar en la cultura española. Psicothema, (16), 288-293.

Orte, C. (2008). Desenvolupament de les competències familiars. La família com a context d'aprenentatge pares-fills. Revista d'Afers Socials, 1, 26-39.

Orte, C., Amer, J.,Pascual, B. \& Vaqué, C. (2014). La perspectiva de los profesionales en la evaluación de un programa de intervención socioeducativa en familias. Pedagogía Social. Revista Interuniversitaria, 24, 163-182.

[80] MARTÍ XAVIER MARCH CERDÀ, CARMEN ORTE SOCIAS Y LLUÍS BALLESTER BRAGE SIPS - PEDAGOGIA SOCIAL. REVISTA INTERUNIVERSITARIA [1139-1723 (2016) 27, 45-82] TERCERA ÉPOCA 
Orte, C., Ballester, L. \& March M.X. (2008) A cluster analysis of families at risk who participated in the strengthening families program in Spain, 2005-07. San Francisco, California: 16 Annual Meeting of the Society for Prevention Research.

Orte, C., Ballester, L., \& March, M. (2013). El enfoque de la competencia familiar, una experiencia de trabajo socioeducativo con familias. Pedagogía Social. Revista Interuniversitaria, 21, 13-37.

Orte, C., March, M.X., Ballester, L., \& Touza, C. (2007). Results of a family competence program adapted for Spanish drug abusing parents. Washington: 15 Annual Meeting of the Society for Prevention Research.

Orte, C., March, M.X., Touza, C., \& Mestre, L. (2009). Material Audiovisual de Apoyo al Programa de Competencia Familiar. Palma de Mallorca: Serveis Audiovisuals: UIB.

Orte, C., Touza, C., \& Ballester, L. (2007). Analisis del grado de fidelidad en la ejecucion de un programa de competencia familiar. Pedagogia Social. Revista Interuniversitaria, 14, 95-103.

Orte, C., \& GIFES. (2005a). Los programas de prevención de drogas centrados en la familia: una visión desde la investigación y la práctica. Revista Proyecto (53), 14-17.

Orte, C., \& GIFES. (2005b). Una investigació educativa sobre un programa de competència familiar. En M. March, Anuari de l'Educació de les Illes Balears (págs. 284-295). Palma: Fundació Guillem Cifre de Colonya.

Pascual, B. (2007). La evaluación de la intervención comunitaria: un marco para la reflexión. Pedagogia Social. Revista Interuniversitaria, 14, 129-138.

Pérez, G. (2003). Pedagogía social, educación social: construcción científica e intervención práctica. Madrid: Narcea Ediciones.

Ruiz, C. (2003). Educación Social: viejos usos y nuevos retos. València: Universitat de València.

Sáez, J. \& Molina, J. (2006). Pedagogía Social: pensar la Educación Social como profesión. Madrid: Alianza Editorial.

Sánchez-Meca, J., Marín-Martínez, F. \& López-López, J.A. (2011). Meta-análisis e Intervención Psicosocial Basada en la Evidencia Meta-analysis and Evidence-Based Psychosocial Intervention. Psychosocial Intervention, 20, 95-107.

Williamson, B. (1992). Lifeworlds and Learning. Studies in the Education of Adults, 24(2), 176-90.

\section{Notas / Notes}

${ }^{1}$ No se consideran, en el cálculo de las plazas, las dos universidades no presenciales. / This calculation doesn't include the seats offered by the two online universities.

\section{CÓMO CITAR ESTE ARTÍCULO / HOW TO CITE THE ARTICLE}

March, M. X., Orte, C., \& Ballester, L (2016). La Pedagogía Social en españa: de la reconstrucción académica y profesional a la incerteza científica y social. Pedagogía Social. Revista Interuniversitaria, 27, 95-132. DOI: 10.7179/PSRI_2016.27.06

Fecha de recepción del artículo / received date: 28.VII.2015

Fecha de revisión del artículo / reviewed date: 12.VIII.2015

Fecha de aceptación final / accepted date: 19.X.2015 
Martí Xavier March Cerdà. Departamento de Pedagogía y didácticas específicas. Edifici Guillem Cifre de Colonya. Campus de la UIB. Carretera de Valldemossa, km, 7.5. Palma de Mallorca. E-mail: martimarch@uib.es

Carmen Orte Socias. Campus UIB. Edifici Guillem Cifre de Colonya. Departament de Pedagogia i Didàctiques Especifiques. Carretera de Valldemossa km. 7,5. 07122 Palma. E-mail: carmen.orte@uib.es

Lluís Ballester Brage. Ctra de Valldemossa, km 7,5. Edifici Guillem Cifre de Colonya. Despatx B 201. 07122 Palma (Illes Balears). E-mail: lluis.ballester@uib.es

\section{PERFIL ACADÉMICO / ACADEMIC PROFILE}

Martí Xavier March Cerdà Licenciado y Doctor en Ciencias de la Educación por la Universidad de Barcelona. Catedrático de Universidad de Pedagogía Social de la Universidad de las Islas Baleares.Coordinador del Grupo de Investigación y Formación Educativo y Social (GIFES) de la UIB.Vicepresidente de la SIPS. Director del Departamento de Ciencias de la Educación y de Pedagogía y Didácticas Específicas de la UIB durante varios años.

Carmen Orte Socias. Licenciada en Psicología y Doctora en Ciencias de la Educación. Profesora de Intervención Socioeducativa en Familias en la UIB, en la que ha desarrollado su tarea docente e investigadora desde el año 1987, fecha en la que entró como Becaria de Formación de Personal Investigador (FPI) del Ministerio de Educación y Ciencia, hasta la actualidad, en la que ejerce como Catedrática de Universidad de Pedagogía de la Inadaptación Social en el Departamento de Pedagogía y Didácticas Específicas de la Universidad Illes Balears (España). Investigadora Principal del Grupo de Investigación y Formación Educativa y Social (GIFES) de la UIB. Más de 300 publicaciones nacionales e internacionales en su ámbito de conocimiento. 50 Proyectos y Contratos de I+D+l financiados en Convocatorias Públicas. Directora de la Cátedra de Atención a la Dependencia y Promoción de la Autonomía Personal de la UIB; Directora de la publicación, Anuari de l'Envelliment Illes Balears desde que lo creó en 2008 y hasta la actualidad. Autora intelectual y directora de la International Summer Senior University desde su creación en 2008. Autora intelectual de la Universitat Oberta per a Majors de la UIB creada en 1998 y de los más de 20 proyectos de educación de mayores en todas las Islas Baleares. Es miembro fundador de la Asociación RANA (Red de Ayuda a Niños Abusados). Es Miembro del Observatorio de la Infancia de Mallorca y Miembro del Observatorio de Mayores de Mallorca.

Lluís Ballester Brage. Doctor en Sociología y en Filosofía, Diplomado en Trabajo Social. Ha trabajado como educador y trabajador social en el Ayuntamiento de Palma, Cáritas y en el Consell de Mallorca. De 1988 a 1996 fue responsable del Departamento de Planificación y Estudios del Área de Bienestar Social y Sanidad del Consell de Mallorca. Desde 1997 es profesor de Métodos de Investigación en la Facultad de Educación de la UIB. De 2002 a 2003 fue el director de la Agencia de Calidad Universitaria de las Islas Baleares. De 2007 a 2011 fue el director del Instituto de Ciencias de la Educación. Miembro del Grupo de Investigación y Formación Educativa y Social (GIFES). Co-director, junto con la profesora Carmen Orte de los cursos de Especialista Universitario sobre prevención y abordaje del Conflicto Juvenil; Coordina, junto con el profesor Josep Lluís Oliver, la evaluación del Programa sobre Pobreza Infantil y Familiar (La Caixa) para las Islas Baleares. Forma parte de la Red de Jóvenes e Inclusión Social, formada por 5 universidades y 8 entidades sociales del Estado. También forma parte, desde hace más de 2003, del Grupo de Estudio de la Prostitución en las Islas Baleares.

[ 82 ] MARTí XAVIER MARCH CERDÀ, CARMEN ORTE SOCIAS Y LLUÍS BALLESTER BRAGE SIPS - PEDAGOGIA SOCIAL. REVISTA INTERUNIVERSITARIA [1139-1723 (2016) 27, 45-82] TERCERA ÉPOCA 